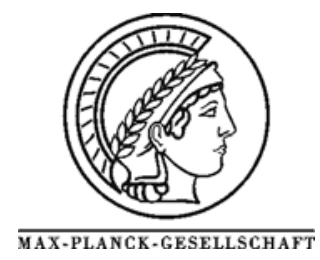

\title{
In situ investigations of the bulk structural evolution of vanadium containing heteropolyoxomolybdate catalysts during thermal activation
}

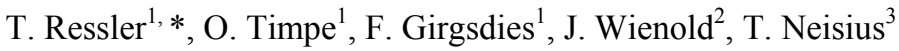 \\ ${ }^{1}$ Department of Inorganic Chemistry, Fritz-Haber-Institute of the MPG, Faradayweg 4-6, 14195 Berlin, Germany \\ ${ }^{2}$ HASYLAB at DESY, Notkestr. 85, D-22603 Hamburg, Germany \\ ${ }^{3}$ European Synchrotron Radiation Facility, BP 220, F-38043 Grenoble Cedex, France
}

* Corresponding author: e-mail ressler@ffhi-berlin.mpg.de, fax +49 3084134405

\begin{abstract}
The bulk structural evolution of a vanadium containing heteropolyoxomolybdate (HPOM), $\mathrm{H}_{4}\left[\mathrm{PVMo}_{11} \mathrm{O}_{40}\right] * 13 \mathrm{H}_{2} \mathrm{O}$, with vanadium substituting for Mo in the Keggin ion was studied under reducing (propene) and partial oxidation reaction conditions (propene and oxygen) by in situ X-ray diffraction (XRD) and X-ray absorption spectroscopy (XAS) combined with mass spectrometry. During treatment in propene, the loss of crystal water in the temperature range from $373 \mathrm{~K}$ to $573 \mathrm{~K}$ is followed by a partial decomposition, reduction of the average Mo valence, and formation of a characteristic cubic HPOM at $573 \mathrm{~K}$. This behavior is similar to the structural evolution of $\mathrm{H}_{3}\left[\mathrm{PMo}_{12} \mathrm{O}_{40}\right] * 13 \mathrm{H}_{2} \mathrm{O}$ during treatment in propene. The formation of cubic $\mathrm{Mo}_{\mathrm{x}}\left[\mathrm{PVMo}_{11-\mathrm{x}} \mathrm{O}_{40}\right]$ with Mo centers on extra Keggin framework positions and $\mathrm{V}$ centers remaining in the lacunary Keggin ion coincides with the onset of catalytic activity at $\sim 573 \mathrm{~K}$. The detailed investigations of the local structure around the vanadium centers in $\mathrm{Mo}_{\mathrm{x}}\left[\mathrm{PVMo}_{11-\mathrm{x}} \mathrm{O}_{40}\right]$ permit to propose a model for the geometric structure of the active site in Mo and $\mathrm{V}$ containing metal oxide catalysts. The cubic $\mathrm{Mo}_{\mathrm{x}}\left[\mathrm{PVMo}_{1-\mathrm{x}} \mathrm{O}_{40}\right]$ phase prepared from $\mathrm{H}_{4}\left[\mathrm{PVMo}_{11} \mathrm{O}_{40}\right] * 13 \mathrm{H}_{2} \mathrm{O}$ is stable in propene and oxygen up to $\sim 620 \mathrm{~K}$ and exhibits an onset of activity at $\sim 573 \mathrm{~K}$. This onset of activity is correlated to characteristic changes in the average local Mo structure indicating a reversible transition from the reduced state of the active site in $\mathrm{Mo}_{\mathrm{x}}\left[\mathrm{PVMo}_{11-\mathrm{x}} \mathrm{O}_{40}\right]$ to an oxidized state under propene oxidation reaction conditions.
\end{abstract}

Keywords: In situ, structure-activity relationships, molybdenum, XAFS spectroscopy, polyoxometalates, partial oxidation, vanadium, heteropoly acids.

\section{Introduction}

Developing more active and selective catalysts for partial oxidation of alkanes and alkenes is extensively pursued in both industrial and academic research. Molybdenum oxide based catalysts for partial oxidation reactions have long been studied and industrially employed. [1] Recently, mixed $\mathrm{MoVNbTeO}_{x}$ catalysts have been reported to possess a superior activity and selectivity for the oxidation of alkanes. [1] At present, the interaction of $\mathrm{Mo}, \mathrm{Nb}$, and $\mathrm{V}$ in these particularly active and selective catalysts is deduced from their arrangement in the ideal crystallographic structure of the as-prepared material. [2] Detailed structure-activity relationships obtained from in situ investigations of these complex mixed oxides remain scarce. However, a rational design of improved catalysts will not be possible without a fundamental understanding of the relationships between the "real" structural and the catalytic properties of the mixed oxide system under reaction conditions.

In order to elucidate the promotional effect of additional metal centers on the catalytic properties of mixed molybdenum oxide catalysts, suitable model systems are sought. Those systems ought to permit to investigate the 
influence of individual metal centers in well-defined oxide catalysts on the structural evolution of the precursor during activation and under reaction conditions while considerably reducing the complexity of the system studied. Heteropolyoxomolybdates (HPOM) are active catalysts for the partial oxidation of alkanes and alkenes. [1, 3, 4, 5, 6] They constitute suitable "real" model systems because of (i) their known structural evolution under reaction conditions, (ii) the similar onset of catalytic activity, which indicates similar active sites for alkene oxidation, and (iii) their potential to accommodate additional metal centers inside or outside of the primary Keggin ion. Moreover, HPOM are often envisaged as ideal model systems because of their reasonably wellunderstood preparations procedures which in principal permit to tailor-make mixed oxide systems. However, with respect to structure-activity relationships it has been shown that the "real" structure of the HPOM catalyst under reaction conditions does not necessarily correspond to the ideal crystallographic structure of the originally prepared Keggin type material. [7, 8] Measuring the catalytic properties of the material needs to be combined with in situ structural investigations of HPOM under reaction conditions to obtain reliable structure-activity correlations.

Recently we were able to show, that migration of molybdenum centers out of the Keggin ion of $\mathrm{H}_{3}\left[\mathrm{PMo}_{12} \mathrm{O}_{40}\right]$ * $13 \mathrm{H}_{2} \mathrm{O}$ onto extra-Keggin sites resulting in a partially decomposed lacunary Keggin ion takes place during thermal activation. [9] Conversely, thermally stable HPOM like, for instance, $\mathrm{Cs}_{3}\left[\mathrm{PMo}_{12} \mathrm{O}_{40}\right]$ whose Keggin ions remain intact at elevated temperatures without a partial decomposition detectable, are catalytically inactive. Thus, the as-prepared and ideal Keggin ion of $\mathrm{H}_{3}\left[\mathrm{PMo}_{12} \mathrm{O}_{40}\right] * 13 \mathrm{H}_{2} \mathrm{O}$ is only the precursor for the active catalyst, which consists of partially reduced and decomposed Keggin ions and Mo centers on extra-Keggin framework positions. A partial decomposition and migration of metal centers has previously been reported for Keggin ions with $[10,11,12,13,14]$ and without addenda substituents. $[15,16,17,18,19,20]$ In particular with respect to the thermal activation of a vanadium containing heteropolyoxomolybdate, $\mathrm{H}_{4}\left[\mathrm{PVMo}_{11} \mathrm{O}_{40}\right] * 13 \mathrm{H}_{2} \mathrm{O}$, it has been proposed that substitution of molybdenum centers by vanadium destabilizes the Keggin ion resulting in a decomposition and migration of vanadium centers out off the Keggin ion. $[8,10,11,12,13,14,16,19,21,22]$

Here, we present in situ X-ray diffraction (XRD) and in situ X-ray absorption spectroscopy (XAS) investigations of $\mathrm{H}_{4}\left[\mathrm{PVMo}_{11} \mathrm{O}_{40}\right] * 13 \mathrm{H}_{2} \mathrm{O}$ during thermal treatment (i.e. activation) under reducing (propene) and catalytic (propene and oxygen) reaction conditions. In addition to a detailed structural characterization of the starting material and the catalyst obtained after thermal activation, we show that a local spectroscopy like XAS that provides a direct "image" of the structure around the vanadium centers is ideally suited to probe the local geometric structure of the active site of vanadium containing polyoxomolybdates.

\section{Experimental}

Preparation of $\mathrm{H}_{4}\left[\mathrm{PVMo}_{11} \mathrm{O}_{40}\right]$ * $13 \mathrm{H}_{2} \mathrm{O}$

$18.58 \mathrm{~g}$ of $\mathrm{MoO}_{3}$ (corresponding to $11.73 \mathrm{mmol} \mathrm{Mo} \mathrm{Mo}_{11}$ ) and $1.067 \mathrm{~g}$ of $\mathrm{V}_{2} \mathrm{O}_{5}$ (corresponding to $11.73 \mathrm{mmol} \mathrm{V}$ ) were suspended in $650 \mathrm{ml}$ water in a three-necked $1000 \mathrm{ml}$ flask equipped with a condenser. Commercial phosphoric acid $\left(\mathrm{H}_{3} \mathrm{PO}_{4}(\sim 82.5 \%)\right)$ was diluted by a factor of 100 and the exact concentration was determined by titration with $\mathrm{NaOH}$. $81 \mathrm{ml}$ of this solution $(11.73 \mathrm{mmol} \mathrm{P})$ were added dropwise to the boiling and stirred suspension of the metal oxides. After complete addition of the phosphoric acid a clear amber colored solution was obtained. The concentration of $\mathrm{H}_{4}\left[\mathrm{PVMo}_{11} \mathrm{O}_{40}\right] * 13 \mathrm{H}_{2} \mathrm{O}$ in this solution was determined by conductometric titration to be $13.8 \mathrm{mmol} / \mathrm{l}$. The solid product was isolated by removing the solvent in a rotary evaporator at $\sim 90{ }^{\circ} \mathrm{C}$ and dried in a vacuum desiccator. $\mathrm{X}$ ray fluorescence analysis afforded a Mo : $\mathrm{V}$ ratio of $11: 1$ in the as-prepared $\mathrm{H}_{4}\left[\mathrm{PVMo}_{11} \mathrm{O}_{40}\right] * 13 \mathrm{H}_{2} \mathrm{O}$ material.

\section{Preparation of $\mathrm{Cs}_{2} \mathrm{H}_{2}\left[\mathrm{PVMo}_{11} \mathrm{O}_{40}\right]$}

$\mathrm{Cs}_{2} \mathrm{CO}_{3}$ was dissolved in water to give a solution of about $110 \mathrm{mmol} / \mathrm{l}$. The exact concentration of the solution was determined by titration with $\mathrm{HCl} .300 \mathrm{ml}$ of the $\mathrm{H}_{4}\left[\mathrm{PVMo}_{11} \mathrm{O}_{40}\right]$ * $13 \mathrm{H}_{2} \mathrm{O}$ solution $(13.8 \mathrm{~mol} / \mathrm{l})$ were heated to $76{ }^{\circ} \mathrm{C}$. An adequate amount of the $\mathrm{Cs}_{2} \mathrm{CO}_{3}$ solution (Cs to $P$ ratio of 2:1) was diluted to $80 \mathrm{ml}$ and added dropwise to the stirred solution of $\mathrm{H}_{4}\left[\mathrm{PVMo}_{11} \mathrm{O}_{40}\right] * 13 \mathrm{H}_{2} \mathrm{O}$. In order to isolate the solid formed, the suspension was first reduced in volume using a rotary evaporator operated at $90{ }^{\circ} \mathrm{C}$. Subsequently, during continuous stirring the remaining slurry was dried on a Petri disk at $90^{\circ} \mathrm{C}$.

\section{$X$-ray diffraction $(X R D)$}

In situ XRD experiments were performed on a STOE Theta/Theta powder diffractometer $\left(\mathrm{Cu} \mathrm{K}_{\alpha}\right.$ radiation, $\mathrm{Si}$ secondary monochromator) and a scintillation counter operated in a stepping mode. The in situ cell consisted of a PAAR $X R K 900$ high temperature diffraction chamber. The gas phase composition at the cell outlet was continuously analyzed with an Omnistar quadropole mass spectrometer (Pfeiffer) in a multiple ion-monitoring mode. In situ XRD measurements were conducted at 1 bar in flowing reactants (flow rate of $100 \mathrm{ml} / \mathrm{min}$ ). Gas phase compositions of $10 \%$ propene in helium, or $10 \%$ propene and $10 \%$ oxygen in helium were employed. XRD patterns were measured every $25 \mathrm{~K}$ in the temperature range from $315 \mathrm{~K}$ to $773 \mathrm{~K}$ resulting in an effective heating rate of $1.3 \mathrm{~K} / \mathrm{min}$. A description of the procedure used can be found in Ref. [23]. Ex situ XRD measurements were performed on a STOE STADI $P$ diffractometer $\left(\mathrm{Cu} \mathrm{Ka} \alpha_{1}\right.$; Ge primary monochromator) in a range of $5^{\circ}-100^{\circ}$ in $2 \theta$ with a step width of $0.01^{\circ}$ and a measuring time of $10 \mathrm{sec} / \mathrm{step}$. Structural refinements to the experimen- 
tal diffraction patterns were performed using the software TOPAS v 2.1 (Bruker AXS). Structural data employed in the XRD and XAS analyses were taken from the Inorganic Crystal Structure Database (ICSD).

\section{X-ray absorption spectroscopy (XAS)}

In situ transmission XAS experiments were performed at the Mo K edge $(19.999 \mathrm{keV})$ at beamline X1 at the Hamburg Synchrotron Radiation Laboratory, HASYLAB, using a Si 311 double crystal monochromator. The storage ring operated at $4.4 \mathrm{GeV}$ with injection currents of $150 \mathrm{~mA}$. The in situ experiments were conducted in a flow-reactor [23, 24] at 1 bar in flowing reactants (flow rate of $30 \mathrm{ml} / \mathrm{min}$, temperature range from $300 \mathrm{~K}$ to $773 \mathrm{~K}$ at $5 \mathrm{~K} / \mathrm{min}$, subsequently held at $773 \mathrm{~K}$ ). The gas phase composition at the cell outlet was continuously analyzed using a mass spectrometer in a multiple ion-monitoring mode (Omnistar from Pfeiffer). The heteropolyoxomolybates were mixed with boron nitride and pressed with a force of 1 ton into a $5 \mathrm{~mm}$ in diameter pellet resulting in an edge jump at the Mo $\mathrm{K}$ edge of $\Delta \mu_{\mathrm{x}} \sim 1.5$ ( $\sim 7 \mathrm{mg}$ HPOM and $\left.\sim 30 \mathrm{mg} \mathrm{BN}\right)$.

Because of the low concentration of vanadium in a heavily absorbing matrix (Mo and Cs atoms), ex situ XAS measurements at the $\mathrm{V} \mathrm{K}$ edge $(5.465 \mathrm{keV})$ were conducted at the „High Brilliance X-ray Spectroscopy Beamline ID26“ at the European Synchrotron Radiation Facility, ESRF. $\mathrm{Mo}_{\mathrm{x}}\left[\mathrm{PVMo}_{11-\mathrm{x}} \mathrm{O}_{40}\right]$ and $\mathrm{Cs}_{2} \mathrm{Mo}_{\mathrm{x}}\left[\mathrm{PVMo}_{11-\mathrm{x}} \mathrm{O}_{40}\right]$ were prepared from $\mathrm{H}_{4}\left[\mathrm{PVMo}_{11} \mathrm{O}_{40}\right] \quad * 13 \quad \mathrm{H}_{2} \mathrm{O}$ and $\mathrm{Cs}_{2} \mathrm{H}_{2}\left[\mathrm{PVMo}_{11} \mathrm{O}_{40}\right]$, respectively, in the in situ XRD set-up according to the procedure described above and sealed in an argon atmosphere. The samples were mixed with cellulose in a ratio of $1: 10$, placed on a sample holder, and measured at $50 \mathrm{~K}$. Spectra were collected in the fluorescence mode with a measuring time of about $7 \mathrm{~min}$.

$\mathrm{X}$-ray absorption fine structure (XAFS) analysis was performed using the software package WinXAS v3.1 [25] following recommended procedures from the literature. [26] Background subtraction and normalization were carried out by fitting linear polynomials to the pre-edge and the postedge region of an absorption spectrum, respectively. The extended X-ray absorption fine structure (EXAFS) $\chi(\mathrm{k})$ was extracted by using cubic splines to obtain a smooth atomic background, $\mu_{0}(\mathrm{k})$. The pseudo radial distribution function FT $\left(\chi(\mathrm{k}) * \mathrm{k}^{3}\right)$ was calculated by Fourier transforming the $\mathrm{k}^{3}$ weighted experimental $\chi(\mathrm{k})$ function, multiplied by a Bessel window, into the $\mathrm{R}$ space. EXAFS data analysis was performed using theoretical backscattering phases and amplitudes calculated with the ab-initio multiple-scattering code FEFF7. [27] Single scattering and multiple scattering paths in the Keggin ion model structure were calculated up to 6.0 $\AA$ with a lower limit of $2.0 \%$ in amplitude with respect to the strongest backscattering path. EXAFS refinements were performed in $\mathrm{R}$ space simultaneously to magnitude and imaginary part of a Fourier transformed $\mathrm{k}^{3}$-weighted and $\mathrm{k}^{1}$ weighted experimental $\chi(\mathrm{k})$ using the standard EXAFS formula. [28] Structural parameters that are determined by a least-squares EXAFS refinement of a Keggin model struc- ture to the experimental spectra are (i) one overall $\mathrm{E}_{0}$ shift, (ii) Debye-Waller factors for single-scattering paths, (iii) distances of single-scattering paths, (iv) one third cumulant for the Mo - O distances in the first coordination shell and one third cumulant for all remaining scattering paths. Coordination numbers $(\mathrm{CN})$ and $\mathrm{S}_{0}{ }^{2}$ were kept invariant in the refinement.

\section{Results}

\section{Characterization of $\mathrm{H}_{4}\left[\mathrm{PVMo}_{11} \mathrm{O}_{40}\right] * 13 \mathrm{H}_{2} \mathrm{O}$}

The ex situ X-ray diffraction pattern of as-prepared $\mathrm{H}_{4}\left[\mathrm{PVMo}_{11} \mathrm{O}_{40}\right] * 13 \mathrm{H}_{2} \mathrm{O}$ is depicted in Figure 1. The simulated pattern shown in Figure 1 was obtained from a refinement of a $\mathrm{H}_{3}\left[\mathrm{PMo}_{12} \mathrm{O}_{40}\right] * 13 \mathrm{H}_{2} \mathrm{O}$ model structure to the experimental pattern $\left(\mathrm{H}_{3}\left[\mathrm{PMo}_{12} \mathrm{O}_{40}\right] * 13 \mathrm{H}_{2} \mathrm{O}, \mathrm{P}-1\right.$, [ICSD $31128, \mathrm{a}=14.10 \AA, \mathrm{b}=14.13 \AA \mathrm{c}=13.55 \AA, \alpha=112.1^{\circ}, \beta$ $\left.=109.8^{\circ}, \gamma=60.7^{\circ}\right] ; \mathrm{H}_{4}\left[\mathrm{PVMo}_{11} \mathrm{O}_{40}\right] * 13 \mathrm{H}_{2} \mathrm{O}, \mathrm{P}-1,[\mathrm{a}=$ $14.08 \AA, b=14.11 \AA \mathrm{c}=13.52 \AA, \alpha=112.1^{\circ}, \beta=109.6^{\circ}, \gamma$ $=60.9^{\circ} \mathrm{]}$, atomic coordinates were kept invariant in the refinement). A schematic representation of the structure of $\mathrm{H}_{4}\left[\mathrm{PVMo}_{11} \mathrm{O}_{40}\right] * 13 \mathrm{H}_{2} \mathrm{O}$ is shown in the inset of Figure 1.

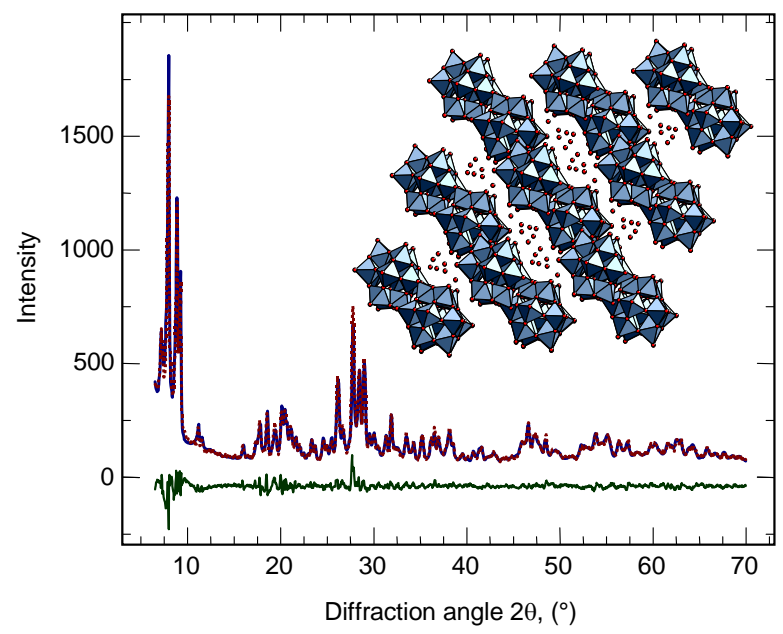

Figure 1: Experimental (dotted) and simulated (solid) X-ray diffraction pattern of as-prepared $\mathrm{H}_{4}\left[\mathrm{PVMo}_{11} \mathrm{O}_{40}\right] * 13 \mathrm{H}_{2} \mathrm{O}$ $\left(\mathrm{P}-1, \mathrm{a}=14.08 \AA, \mathrm{b}=14.11 \AA \mathrm{c}=13.52 \AA, \alpha=112.1^{\circ}, \beta=\right.$ $109.6^{\circ}, \gamma=60.9^{\circ}$ ). The inset shows a schematic structural representation of $\mathrm{H}_{4}\left[\mathrm{PVMo}_{11} \mathrm{O}_{40}\right] * 13 \mathrm{H}_{2} \mathrm{O}$.

The evolution of the relative sample weight (TG) during thermal treatment of $\mathrm{H}_{4}\left[\mathrm{PVMo}_{11} \mathrm{O}_{40}\right] * 13 \mathrm{H}_{2} \mathrm{O}$ in oxygen has been previously described [21]. A weight loss detected in the temperature range from $300 \mathrm{~K}$ to $523 \mathrm{~K}$ corresponds to the loss of crystal water from as-prepared $\mathrm{H}_{4}\left[\mathrm{PVMo}_{11} \mathrm{O}_{40}\right]$ * $13 \mathrm{H}_{2} \mathrm{O}$. A further weight loss, a second peak in the water signal, and an endothermic DSC signal at $573 \mathrm{~K}$ correspond to the loss of so-called structural water of $\mathrm{H}_{4}\left[\mathrm{PVMo}_{11} \mathrm{O}_{40}\right]$ * $13 \mathrm{H}_{2} \mathrm{O}$. As will be discussed later this temperature coincides with the onset of catalytic activity. UV-Vis spectra of $\mathrm{H}_{4}\left[\mathrm{PVMo}_{11} \mathrm{O}_{40}\right] * 13 \mathrm{H}_{2} \mathrm{O}$ measured in solution exhibited an 
Table 1: Structural parameters (type of pairs and number $(\mathrm{N})$ of nearest neighbors at distance $\mathrm{R}$ ) obtained from a refinement of a Keggin ion model structure (based on ICSD 209, Table 2) to the experimental XAFS functions $\chi(\mathrm{k})$ of $\mathrm{H}_{4}\left[\mathrm{PVMo}_{11} \mathrm{O}_{40}\right]^{*} 13 \mathrm{H}_{2} \mathrm{O}$ (Figure 4) and cubic $\mathrm{Mo}_{\mathrm{x}}\left[\mathrm{PVMo}_{11-\mathrm{x}} \mathrm{O}_{40}\right]$ (Figure 4) at the V K edge $\left(\mathrm{N}_{\text {ind }}=35, \mathrm{~N}_{\text {free }}=20,12\right.$ single scattering paths and 7 multiple scattering paths, $\mathrm{E}_{0}=-7.3 \mathrm{eV}$ ).

\begin{tabular}{|c|c|c|c|c|c|c|c|c|}
\hline \multicolumn{3}{|c|}{$\mathrm{H}_{4}\left[\mathrm{PVMo}_{11} \mathrm{O}_{40}\right] * 13 \mathrm{H}_{2} \mathrm{O}$ (Model) } & \multicolumn{3}{|c|}{$\mathrm{H}_{4}\left[\mathrm{PVMo}_{11} \mathrm{O}_{40}\right] * 13 \mathrm{H}_{2} \mathrm{O}$} & \multicolumn{3}{|c|}{$\mathrm{Mo}_{\mathrm{x}}\left[\mathrm{PVMo}_{11-\mathrm{x}} \mathrm{O}_{40}\right]$} \\
\hline Type & $\mathrm{N}$ & $\mathrm{R}, \AA$ & $\mathrm{N}$ & $\mathrm{R}, \AA$ & $\sigma^{2}, \AA^{2}$ & $\mathrm{~N}$ & $\mathrm{R}, \AA$ & $\sigma^{2}, \AA^{2}$ \\
\hline $\mathrm{V}-\mathrm{O}$ & 1 & 1.71 & 1 & 1.62 & 0.0038 & 1 & 1.64 & 0.0048 \\
\hline $\mathrm{V}-\mathrm{O}$ & 2 & 1.91 & 2 & 1.97 & 0.0040 & 2 & 2.00 & 0.0054 \\
\hline $\mathrm{V}-\mathrm{O}$ & 2 & 1.92 & 2 & 1.97 & 0.0040 & 2 & 2.00 & 0.0054 \\
\hline $\mathrm{V}-\mathrm{O}$ & 1 & 2.46 & 1 & 2.46 & 0.0042 & 1 & 2.44 & 0.0038 \\
\hline V-Mo & 2 & 3.42 & 2 & 3.33 & 0.0063 & 2 & 3.44 & 0.0051 \\
\hline V-P & 1 & 3.57 & 1 & 3.50 & 0.001 & 1 & 3.52 & 0.001 \\
\hline V-Mo & 2 & 3.72 & 2 & 3.68 & 0.0024 & 2 & 3.66 & 0.0039 \\
\hline V-Mo & 2 & 4.89 & 2 & 4.86 & 0.0086 & 2 & 4.92 & 0.0066 \\
\hline V-Mo & 2 & 5.02 & 2 & 5.04 & 0.0086 & 2 & 5.08 & 0.0066 \\
\hline V-Mo & & & - & - & - & 0.6 & 2.84 & 0.0051 \\
\hline
\end{tabular}

additional band compared to $\mathrm{H}_{3}\left[\mathrm{PMo}_{12} \mathrm{O}_{40}\right] * 13 \mathrm{H}_{2} \mathrm{O}$ indicating the incorporation of vanadium in the Keggin ion.

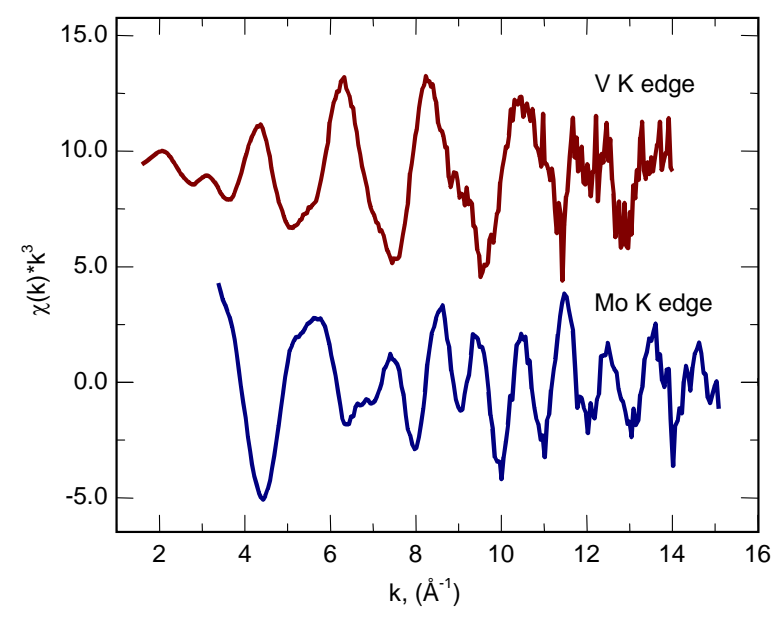

Figure 2: Experimental XAFS $\chi(\mathrm{k}) * \mathrm{k}^{3}$ of $\mathrm{H}_{4}\left[\mathrm{PVMo}_{11} \mathrm{O}_{40}\right]$ * $13 \mathrm{H}_{2} \mathrm{O}$ measured at the $\mathrm{V} \mathrm{K}$ edge $(50 \mathrm{~K})$ and at the Mo $\mathrm{K}$ edge (room temperature, $4.5 \mathrm{~min} / \mathrm{spectrum}$ ).

Figure 2 shows two experimental XAFS $\chi(\mathrm{k}) * \mathrm{k}^{3}$ of $\mathrm{H}_{4}\left[\mathrm{PVMo}_{11} \mathrm{O}_{40}\right] * 13 \mathrm{H}_{2} \mathrm{O}$ measured at the Mo and $\mathrm{V} \mathrm{K}$ edges at $300 \mathrm{~K}$ and at $50 \mathrm{~K}$, respectively. The Mo K edge spectrum was measured in about $4.5 \mathrm{~min}$. The signal to noise ratio up to $14 \AA^{-1}$ at the V K edge and $15 \AA^{-1}$ at the Mo $\mathrm{K}$ edge is certainly sufficient for the XAFS analysis described below. The experimental and theoretical Mo $\mathrm{K}$ edge $\mathrm{FT}\left(\chi(\mathrm{k}) * \mathrm{k}^{3}\right)$ of $\mathrm{H}_{4}\left[\mathrm{PVMo}_{11} \mathrm{O}_{40}\right] * 13 \mathrm{H}_{2} \mathrm{O}$ and

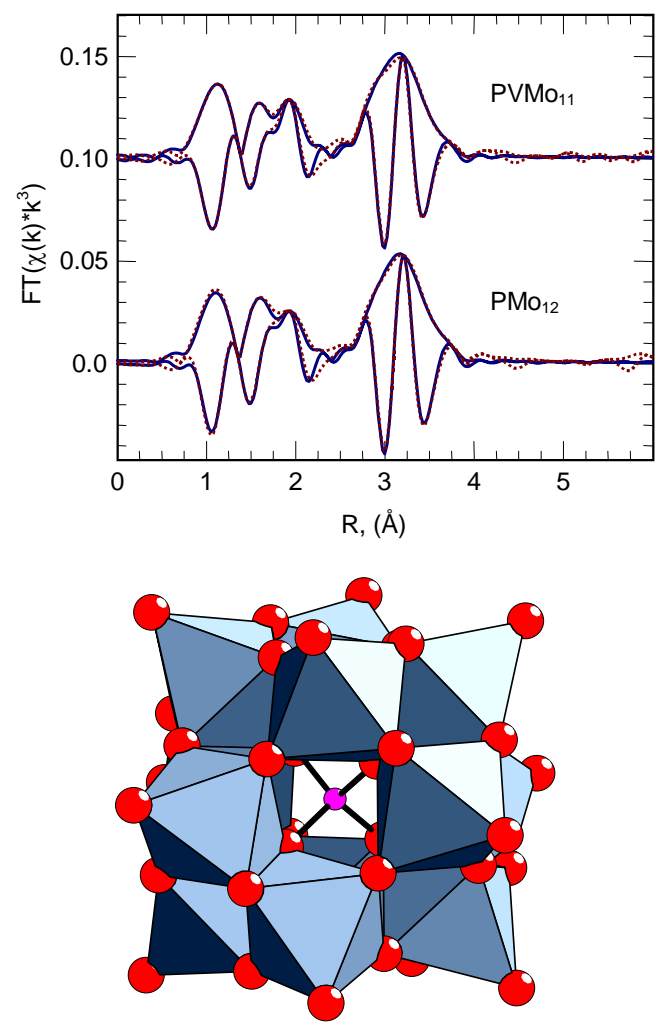

Figure 3: (A) Experimental (dotted) and theoretical (solid) $\mathrm{FT}\left(\chi(\mathrm{k}) * \mathrm{k}^{3}\right)$ of the Mo K edge spectra of $\mathrm{H}_{4}\left[\mathrm{PVMo}_{11} \mathrm{O}_{40}\right]$ * $13 \mathrm{H}_{2} \mathrm{O}\left(\mathrm{PVMo}_{11}\right)$ and $\mathrm{H}_{3}\left[\mathrm{PMo}_{12} \mathrm{O}_{40}\right] * 13 \mathrm{H}_{2} \mathrm{O}\left(\mathrm{PMo}_{12}\right)$ together with (B) a schematic representation of the Keggin ion. 
$\mathrm{H}_{3}\left[\mathrm{PMo}_{12} \mathrm{O}_{40}\right] * 13 \mathrm{H}_{2} \mathrm{O}$ are depicted in Figure 3, together with a schematic representation of the Keggin ion. The theoretical $\mathrm{FT}\left(\chi(\mathrm{k}) * \mathrm{k}^{3}\right)$ were obtained from a refinement of a Keggin model structure to the Mo $\mathrm{K}$ edge data of $\mathrm{H}_{4}\left[\mathrm{PVMo}_{11} \mathrm{O}_{40}\right] * 13 \mathrm{H}_{2} \mathrm{O}$ and $\mathrm{H}_{3}\left[\mathrm{PMo}_{12} \mathrm{O}_{40}\right] * 13 \mathrm{H}_{2} \mathrm{O}$.

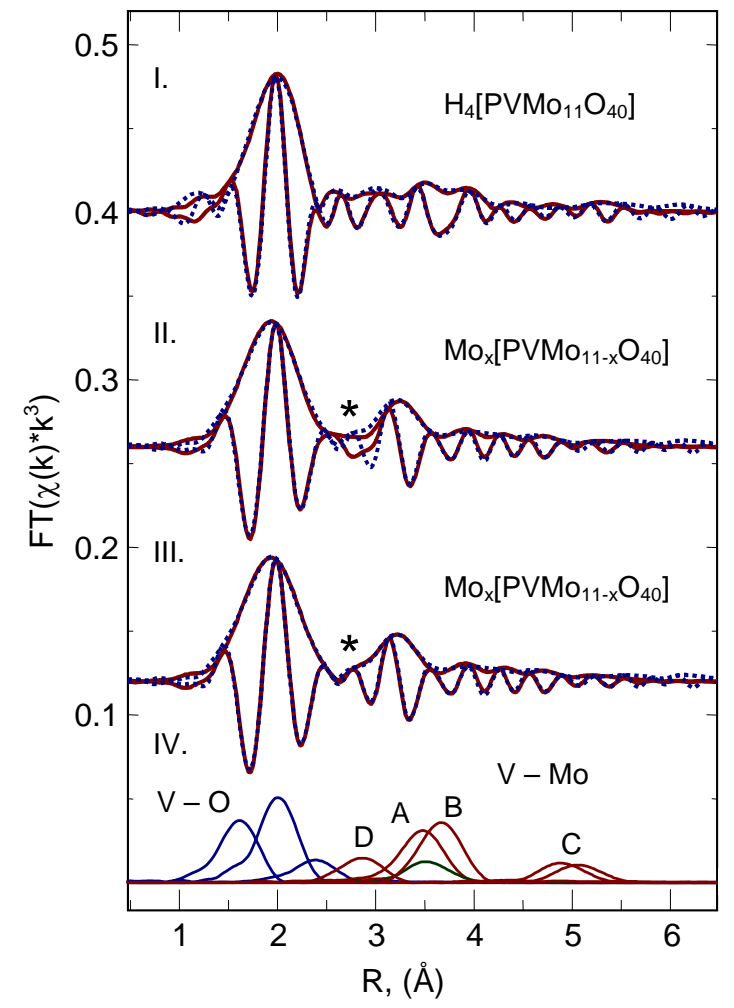

Figure 4: Experimental (dotted) and theoretical (solid, Table 1) $\mathrm{FT}\left(\chi(\mathrm{k}) * \mathrm{k}^{3}\right)$ of the $\mathrm{V} \mathrm{K}$ edge spectra of (I.) $\mathrm{H}_{4}\left[\mathrm{PVMo}_{11} \mathrm{O}_{40}\right] * 13 \mathrm{H}_{2} \mathrm{O}$, (II.) $\mathrm{Mo}_{\mathrm{x}}\left[\mathrm{PVMo}_{11-\mathrm{x}} \mathrm{O}_{40}\right]$ without taking shell D into account, (III.) $\mathrm{Mo}_{\mathrm{x}}\left[\mathrm{PVMo}_{11-\mathrm{x}} \mathrm{O}_{40}\right]$ taking shell D into account, and (IV.) single scattering shells in the local structure around the $\mathrm{V}$ center in the Keggin ion (schematic representation in Figure 5). The $\mathrm{FT}\left(\chi(\mathrm{k}) * \mathrm{k}^{3}\right)$ have been arbitrarily phase corrected by a shift of $0.4 \AA$.

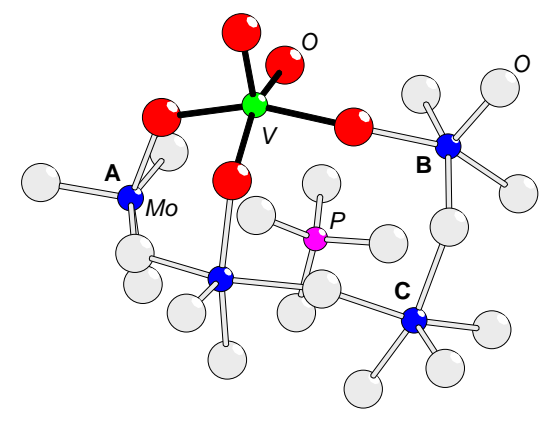

Figure 5: Schematic representation of the local structure around the $\mathrm{V}$ center in the Keggin ion of $\mathrm{H}_{4}\left[\mathrm{PVMo}_{11} \mathrm{O}_{40}\right]$ * $13 \mathrm{H}_{2} \mathrm{O}$. The neighboring Mo centers are indicated (A: VMo at 3.4 $\AA$, B: V-Mo at 3.8 $\AA, \mathrm{C}$ : V-Mo at $5 \AA$ ).

The local structure parameters obtained correspond to those reported in the literature [9] with insignificant deviations between $\mathrm{H}_{4}\left[\mathrm{PVMo}_{11} \mathrm{O}_{40}\right] * 13 \quad \mathrm{H}_{2} \mathrm{O}$ and
$\mathrm{H}_{3}\left[\mathrm{PMo}_{12} \mathrm{O}_{40}\right] * 13 \mathrm{H}_{2} \mathrm{O}$. The experimental and theoretical V K edge $\mathrm{FT}\left(\chi(\mathrm{k}) * \mathrm{k}^{3}\right)$ of $\mathrm{H}_{4}\left[\mathrm{PVMo}_{11} \mathrm{O}_{40}\right] * 13 \mathrm{H}_{2} \mathrm{O}$ is depicted in Figure 4(I.). The theoretical $\mathrm{FT}\left(\chi(\mathrm{k}) * \mathrm{k}^{3}\right)$ was obtained from a refinement of a Keggin model structure to the $\mathrm{V} \mathrm{K}$ edge data of $\mathrm{H}_{4}\left[\mathrm{PVMo}_{11} \mathrm{O}_{40}\right] * 13 \mathrm{H}_{2} \mathrm{O}$. The local structure parameters obtained are presented in Table 1. The local structure around a V center in the Keggin ion is shown in Figure 5.

\section{Thermal treatment of $\mathrm{H}_{4}\left[\mathrm{PVMo}_{11} \mathrm{O}_{40}\right]$ * $13 \mathrm{H}_{2} \mathrm{O}$ in pro- pene}

The evolution of XRD patterns measured during thermal treatment of $\mathrm{H}_{4}\left[\mathrm{PVMo}_{11} \mathrm{O}_{40}\right] * 13 \mathrm{H}_{2} \mathrm{O}$ in $10 \%$ propene in the temperature range from $323 \mathrm{~K}$ to $723 \mathrm{~K}$ resembles that presented in the literature for the thermal treatment of $\mathrm{H}_{3}\left[\mathrm{PMo}_{12} \mathrm{O}_{40}\right] * 13 \mathrm{H}_{2} \mathrm{O}$. [9] Under these conditions a single-phase cubic HPOM is obtained at $773 \mathrm{~K}$ without further decomposition and reduction to $\mathrm{MoO}_{2}$. The background corrected and normalized XRD pattern of the cubic HPOM at $300 \mathrm{~K}$ in comparison to that obtained from a thermal treatment of $\mathrm{H}_{3}\left[\mathrm{PMo}_{12} \mathrm{O}_{40}\right] * 13 \mathrm{H}_{2} \mathrm{O}$ is depicted in Figure 6. Except for the strongest peak at about $27^{\circ}$ a very good

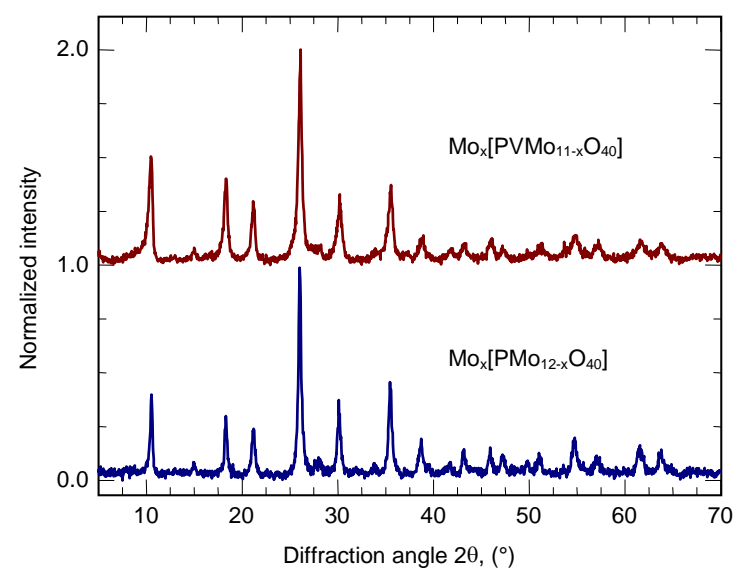

Figure 6: Comparison of the experimental XRD patterns of cubic $\mathrm{Mo}_{\mathrm{x}}\left[\mathrm{PVMo}_{11-\mathrm{x}} \mathrm{O}_{40}\right]$ and $\mathrm{Mo}_{\mathrm{x}}\left[\mathrm{PMo}_{12-\mathrm{x}} \mathrm{O}_{40}\right]$ obtained from thermal treatment of $\mathrm{H}_{4}\left[\mathrm{PVMo}_{11} \mathrm{O}_{40}\right] * 13 \mathrm{H}_{2} \mathrm{O}$ and $\mathrm{H}_{4}\left[\mathrm{PMo}_{12} \mathrm{O}_{40}\right] * 13 \mathrm{H}_{2} \mathrm{O}$, respectively, in $10 \%$ propene in He.

agreement between the intensity ratios of the peaks in both experimental patterns can be seen. The simulated diffraction pattern shown in Figure 7A was obtained from a refinement of the structure of cubic $\mathrm{Mo}_{\mathrm{x}}\left[\mathrm{PVMo}_{11-\mathrm{x}} \mathrm{O}_{40}\right]$ to the experimental pattern. The structural data determined for $\mathrm{Mo}_{\mathrm{x}}\left[\mathrm{PVMo}_{11-\mathrm{x}} \mathrm{O}_{40}\right]$ are given in Table 2. A schematic representation of cubic $\mathrm{Mo}_{\mathrm{x}}\left[\mathrm{PVMo}_{11-\mathrm{x}} \mathrm{O}_{40}\right]$ is depicted in Figure 7B.

The evolution of the Mo $\mathrm{K}$ near-edge spectra of $\mathrm{H}_{4}\left[\mathrm{PVMo}_{11} \mathrm{O}_{40}\right] * 13 \mathrm{H}_{2} \mathrm{O}$ resembles that of $\mathrm{H}_{3}\left[\mathrm{PMo}_{12} \mathrm{O}_{40}\right]$ * $13 \mathrm{H}_{2} \mathrm{O}$ as reported in Ref. [9]. A refinement of a Keggin 
Table 2: Atom coordinates in the unit cell of $\mathrm{Mo}_{\mathrm{x}}\left[\mathrm{PVMo}_{11-}\right.$ ${ }_{\mathrm{x}} \mathrm{O}_{40}$ ] obtained from a refinement of a structural model based on $\mathrm{K}_{2} \mathrm{H}\left[\mathrm{PMo}_{12} \mathrm{O}_{40}\right] * \mathrm{H}_{2} \mathrm{O}$ (ICSD 209, Pn-3mZ, a = $11.6 \AA$ ] with $\mathrm{K}$ and $\mathrm{H}_{2} \mathrm{O}$ omitted) with a molybdenum center (Mo2) on an extra-Keggin framework position (Pn$3 \mathrm{mZ}, \mathrm{a}=11.861 \AA$ ). Atom coordinates were kept invariant in the refinement except for the coordinates of the extraKeggin Mo center.

\begin{tabular}{lllll}
\hline Site & $x$ & $y$ & $z$ & Occ \\
\hline Mo1 & 0.4670 & 0.4670 & 0.2587 & $0.94(2)$ \\
O1 & 0.6528 & 0.6528 & 0.0060 & 1 \\
O2 & 0.0689 & 0.0689 & 0.7670 & 1 \\
O3 & 0.1233 & 0.1233 & 0.5398 & 1 \\
O4 & 0.3273 & 0.3273 & 0.3273 & 1 \\
P1 & 0.2500 & 0.2500 & 0.2500 & 1 \\
Mo2 & $0.403(3)$ & $0.764(3)$ & $0.764(3)$ & $0.15(1)$ \\
\hline
\end{tabular}
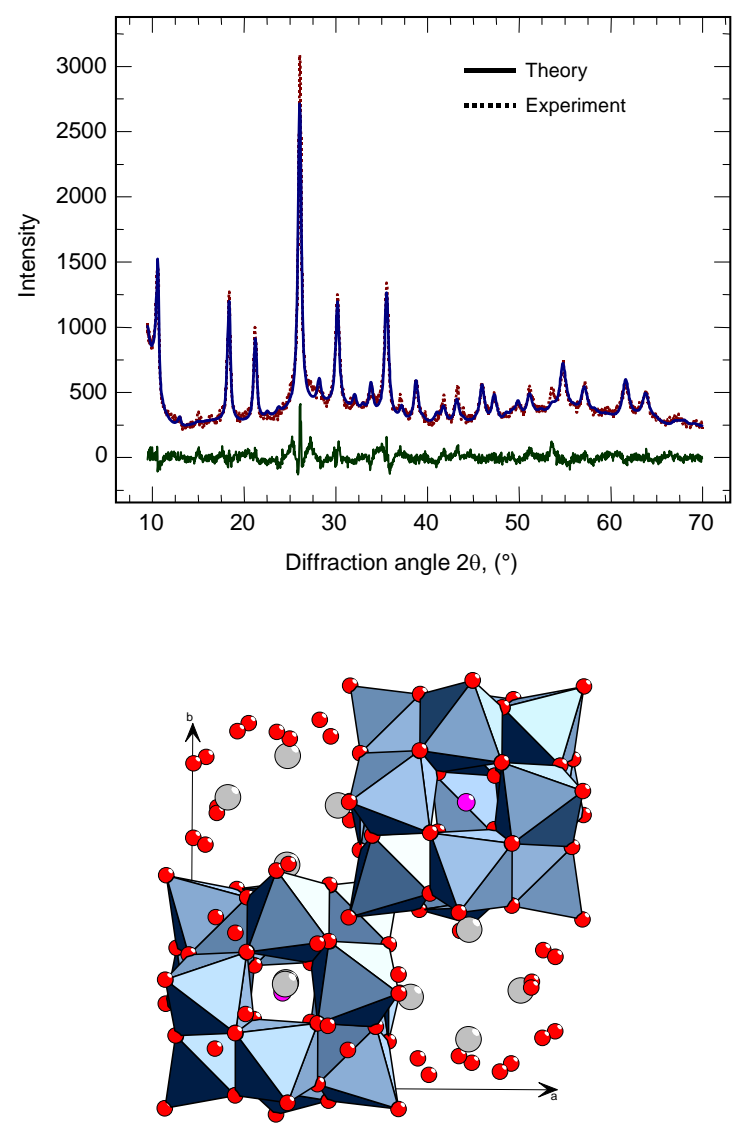

Figure 7: (A) Experimental and simulated XRD patterns of cubic $\mathrm{Mo}_{\mathrm{x}}\left[\mathrm{PVMo}_{11-\mathrm{x}} \mathrm{O}_{40}\right]$ (Table 2) obtained from thermal treatment of $\mathrm{H}_{4}\left[\mathrm{PVMo}_{11} \mathrm{O}_{40}\right] * 13 \mathrm{H}_{2} \mathrm{O}$ in $10 \%$ propene in He from $300 \mathrm{~K}$ to $773 \mathrm{~K}$. (B) Schematic structural representation of the cubic $\mathrm{Mo}_{\mathrm{x}}\left[\mathrm{PVMo}_{11-\mathrm{x}} \mathrm{O}_{40}\right]$ phase. model structure to the experimental Mo $\mathrm{K}$ edge $\mathrm{FT}\left(\chi(\mathrm{k})^{*} \mathrm{k}^{3}\right)$ of $\mathrm{Cs}_{2} \mathrm{H}_{2}\left[\mathrm{PVMo}_{11} \mathrm{O}_{40}\right]$ and $\mathrm{Cs}_{2} \mathrm{H}\left[\mathrm{PMo}_{12} \mathrm{O}_{40}\right]$ during thermal treatment in $10 \%$ propene was performed to elucidate the evolution of the average local structure around a Mo center. For the comparison of the structural evolution of the $\mathrm{V}$ containing and the $\mathrm{V}$ free Keggin ion, the Cs salts of $\mathrm{H}_{4}\left[\mathrm{PVMo}_{11} \mathrm{O}_{40}\right] * 13 \quad \mathrm{H}_{2} \mathrm{O}$ and $\mathrm{H}_{3}\left[\mathrm{PMo}_{12} \mathrm{O}_{40}\right] * 13 \mathrm{H}_{2} \mathrm{O}$ were chosen because of their superior thermal stability against decomposition to $\mathrm{MoO}_{3}$. The presence of a major amount of $\mathrm{MoO}_{3}$ would render a reliable determination of the average local Keggin structure under reaction conditions more difficult. The evolution of selected Mo - $\mathrm{O}$ and Mo - Mo distances in the average local structure around a Mo center in $\mathrm{Cs}_{2} \mathrm{H}_{2}\left[\mathrm{PVMo}_{11} \mathrm{O}_{40}\right]$ and $\mathrm{Cs}_{2} \mathrm{H}\left[\mathrm{PMo}_{12} \mathrm{O}_{40}\right]$ during thermal treatment in $10 \%$ propene is depicted in Figure 8. At temperatures above 573 $\mathrm{K}$ a significant increase in the selected $\mathrm{Mo}-\mathrm{O}$ and $\mathrm{Mo}-$ Mo distances can be seen. For the Mo - Mo distances chosen the structural transformation appears to be finished at $700 \mathrm{~K}$ resulting in a stable phase upon further heating.

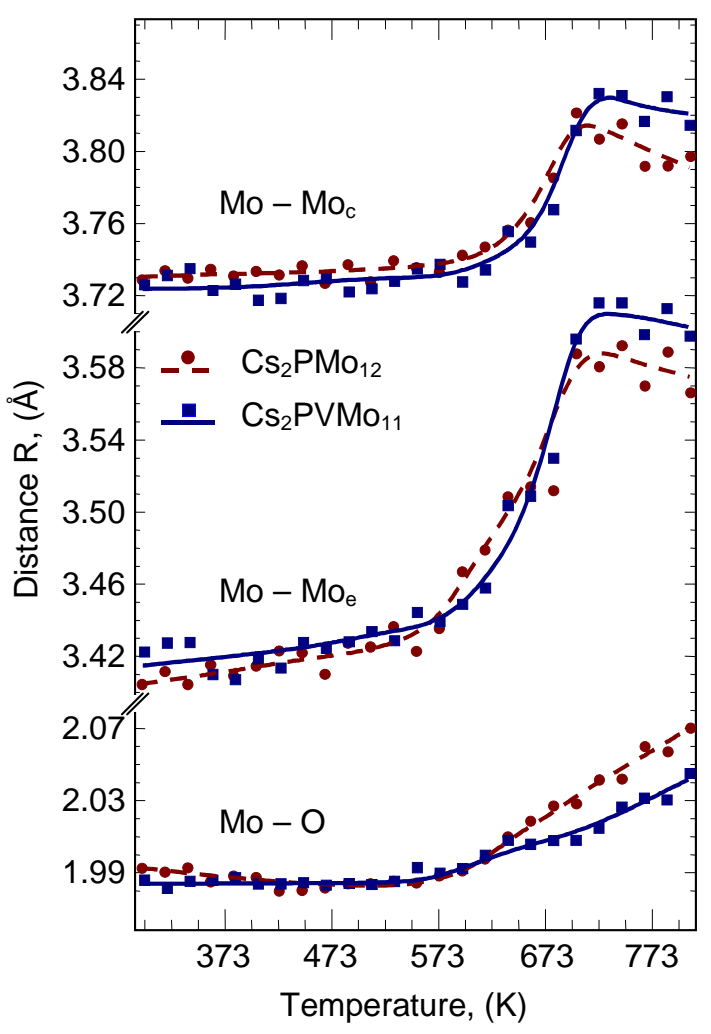

Figure 8: Evolution of representative $\mathrm{Mo}-\mathrm{O}$ and $\mathrm{Mo}-$ Mo distances in the average local structure around a Mo center in $\mathrm{Cs}_{2} \mathrm{H}_{2}\left[\mathrm{PVMo}_{11} \mathrm{O}_{40}\right]$ and $\mathrm{Cs}_{2} \mathrm{H}\left[\mathrm{PMo}_{12} \mathrm{O}_{40}\right]$ in $10 \%$ propene in $\mathrm{He}$. The dashed line indicates the onset of catalytic activity.

The V K near-edge spectra of $\mathrm{H}_{4}\left[\mathrm{PVMo}_{11} \mathrm{O}_{40}\right] * 13$ $\mathrm{H}_{2} \mathrm{O}$, cubic $\mathrm{Mo}_{\mathrm{x}}\left[\mathrm{PVMo}_{11-\mathrm{x}} \mathrm{O}_{40}\right]$, and various vanadium oxide references $\left(\mathrm{V}_{2} \mathrm{O}_{3}, \mathrm{VO}_{2}, \mathrm{~V}_{2} \mathrm{O}_{5}\right)$ are depicted in Figure 9. The reduction in the height of the characteristic $\mathrm{V}$ K pre- 


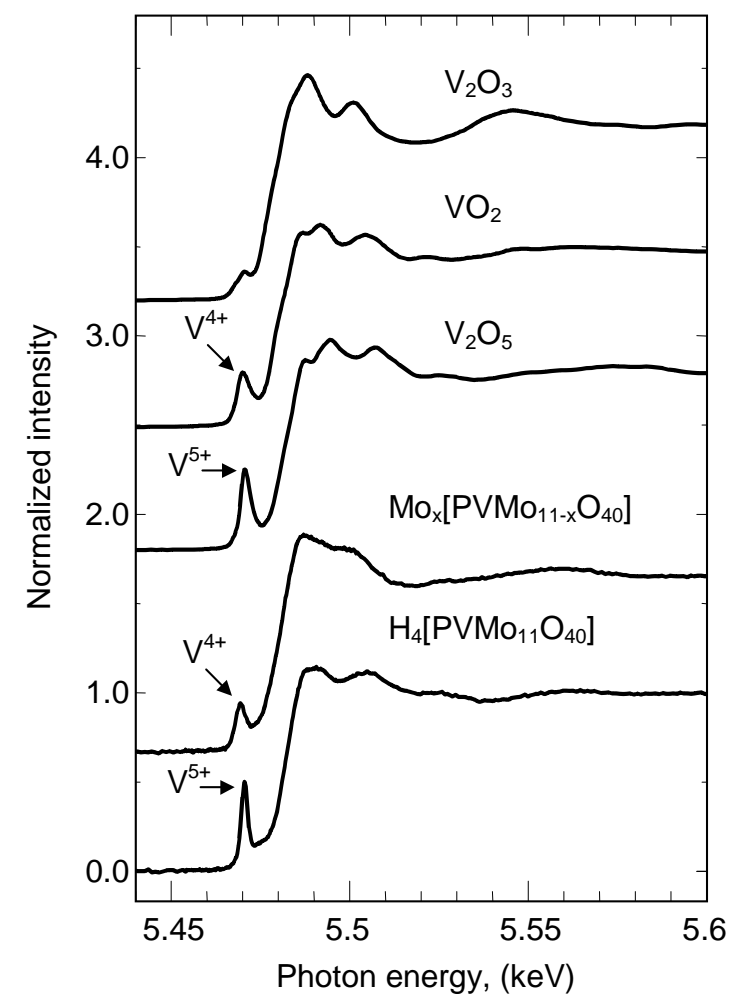

Figure 9: V K near-edge spectra of $\mathrm{H}_{4}\left[\mathrm{PVMo}_{11} \mathrm{O}_{40}\right] * 13$ $\mathrm{H}_{2} \mathrm{O}, \mathrm{Mo}_{\mathrm{x}}\left[\mathrm{PVMo}_{11-\mathrm{x}} \mathrm{O}_{40}\right]$, and various vanadium oxide references $\left(\mathrm{V}_{2} \mathrm{O}_{3}, \mathrm{VO}_{2}, \mathrm{~V}_{2} \mathrm{O}_{5}\right)$.

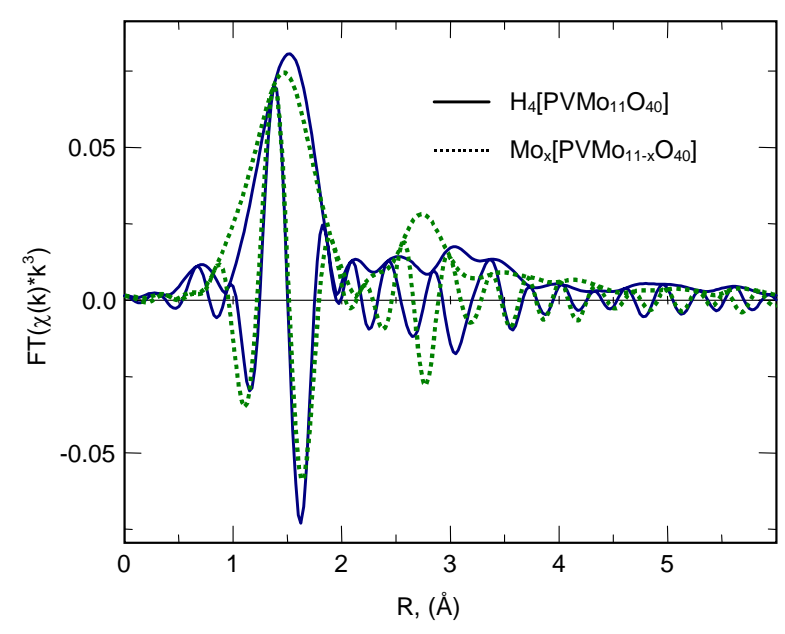

Figure 10: Experimental $\left.\mathrm{FT}(\chi(\mathrm{k}))^{*} \mathrm{k}^{3}\right)$ of the $\mathrm{V} \mathrm{K}$ edge spectra of $\mathrm{H}_{4}\left[\mathrm{PVMo}_{11} \mathrm{O}_{40}\right] * 13 \mathrm{H}_{2} \mathrm{O}\left(\mathrm{PVMo}_{11}\right.$, solid) and $\mathrm{Mo}_{\mathrm{x}}\left[\mathrm{PVMo}_{11-\mathrm{x}} \mathrm{O}_{40}\right]$ (dotted).

edge peak at $5.47 \mathrm{keV}$ indicates a reduction of mostly $\mathrm{V}^{5+}$ in $\mathrm{H}_{4}\left[\mathrm{PVMo}_{11} \mathrm{O}_{40}\right] * 13 \quad \mathrm{H}_{2} \mathrm{O}$ to mostly $\mathrm{V}^{4+}$ in $\mathrm{Mo}_{\mathrm{x}}\left[\mathrm{PVMo}_{11-\mathrm{x}} \mathrm{O}_{40}\right]$. Figure 4 (II.) shows the $\mathrm{FT}\left(\chi(\mathrm{k})^{*} \mathrm{k}^{3}\right)$ of cubic $\mathrm{Mo}_{\mathrm{x}}\left[\mathrm{PVMo}_{11-\mathrm{x}} \mathrm{O}_{40}\right]$ together with a theoretical refinement of the local structure around a V center substituting for Mo in the Keggin ion. The structural parameters determined are given in Table 1. The refinement results in a good agreement in the range between 1.5 and $2.5 \AA$ and between 3.5 and $5.0 \AA$. However, a considerable deviation between experimental data and simulation can be observed at about $2.9 \AA$. Only after extending the simulation by an additional Mo - Mo shell at about $2.9 \AA$ (D in Figure 4 (IV.)), could a satisfying agreement between theory and simulation over the entire data range be obtained (Figure 4 (III.)). A comparison between the V K edge $\mathrm{FT}\left(\chi(\mathrm{k})^{*} \mathrm{k}^{3}\right)$ of $\mathrm{H}_{4}\left[\mathrm{PVMo}_{11} \mathrm{O}_{40}\right] * 13 \mathrm{H}_{2} \mathrm{O}$ and cubic $\mathrm{Mo}_{\mathrm{x}}\left[\mathrm{PVMo}_{11-\mathrm{x}} \mathrm{O}_{40}\right]$ is depicted in Figure 10. Evidently, that the two $\mathrm{FT}\left(\chi(\mathrm{k}) * \mathrm{k}^{3}\right)$ agree reasonably well at around $2.0 \AA$ and in the range from 3.2 to $6.0 \AA$, whereas considerable deviations can be seen between 2.5 and $3.2 \AA$.

Thermal activation of $\mathrm{H}_{4}\left[\mathrm{PVMo}_{11} \mathrm{O}_{40}\right]$ * $13 \mathrm{H}_{2} \mathrm{O}$ in propene and oxygen

From Mo K edge XANES spectra measured during thermal treatment of $\mathrm{Cs}_{2} \mathrm{H}_{2}\left[\mathrm{PVMo}_{11} \mathrm{O}_{40}\right]$ and $\mathrm{Cs}_{2} \mathrm{H}\left[\mathrm{PMo}_{12} \mathrm{O}_{40}\right]$ in $10 \%$ propene and $10 \%$ oxygen in $\mathrm{He}$ an average Mo valence was determined according to the procedure reported in Ref. [29]. Figure 11 shows the evolution of the Mo average valence together with the normalized propene conversion. $\mathrm{Cs}_{2} \mathrm{H}_{2}\left[\mathrm{PVMo}_{11} \mathrm{O}_{40}\right]$ and $\mathrm{Cs}_{2} \mathrm{H}\left[\mathrm{PMo}_{12} \mathrm{O}_{40}\right]$ exhibit the same onset of catalytic activity at $\sim 573 \mathrm{~K}$ which roughly correlates with a partial reduction of the molybdenum in the Keggin ions. Compared to $\mathrm{Cs}_{2} \mathrm{H}\left[\mathrm{PMo}_{12} \mathrm{O}_{40}\right]$, the Mo centers in $\mathrm{Cs}_{2} \mathrm{H}_{2}\left[\mathrm{PVMo}_{11} \mathrm{O}_{40}\right]$ appear to be reduced at slightly lower temperatures.

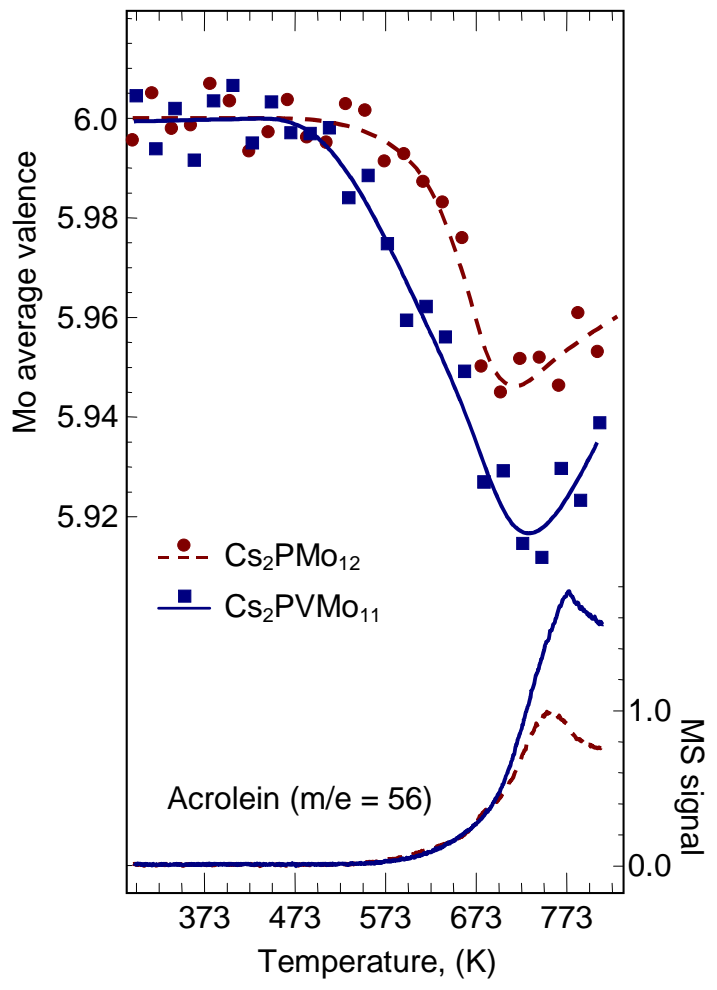

Figure 11: Evolution of average Mo valence obtained from Mo $\mathrm{K}$ edge XANES spectra measured during thermal treatment of $\mathrm{Cs}_{2} \mathrm{H}_{2}\left[\mathrm{PVMo}_{11} \mathrm{O}_{40}\right]$ and $\mathrm{Cs}_{2} \mathrm{H}\left[\mathrm{PMo}_{12} \mathrm{O}_{40}\right]$ in 10 $\%$ propene and $10 \%$ oxygen in He together with the normalized ion current of acrolein $(\mathrm{m} / \mathrm{e}=56)$. 
At temperatures above $700 \mathrm{~K}$ a decrease in the catalytic activity can be seen which coincides with an oxidation of the molybdenum and a possibly decomposition of the HPOM. A Keggin model structure was refined to the experimental Mo K edge $\mathrm{FT}\left(\chi(\mathrm{k}) * \mathrm{k}^{3}\right)$ of $\mathrm{Cs}_{2} \mathrm{H}_{2}\left[\mathrm{PVMo}_{11} \mathrm{O}_{40}\right]$ and $\mathrm{Cs}_{2} \mathrm{H}\left[\mathrm{PMo}_{12} \mathrm{O}_{40}\right]$ measured during thermal treatment in $10 \%$ propene and $10 \%$ oxygen to determine the structural evolution during activation. Characteristic changes in selected Mo - O and Mo - Mo distances during thermal treatment in propene and oxygen are shown in Figure 12 together with the propene conversion. The onset of catalytic activity coincides with an increase in the $\mathrm{Mo}-\mathrm{O}$ and Mo - Mo distance in both $\mathrm{Cs}_{2} \mathrm{H}_{2}\left[\mathrm{PVMo}_{11} \mathrm{O}_{40}\right]$ and $\mathrm{Cs}_{2} \mathrm{H}\left[\mathrm{PMo}_{12} \mathrm{O}_{40}\right]$, while the amplitude of the changes detected is very similar in both materials.

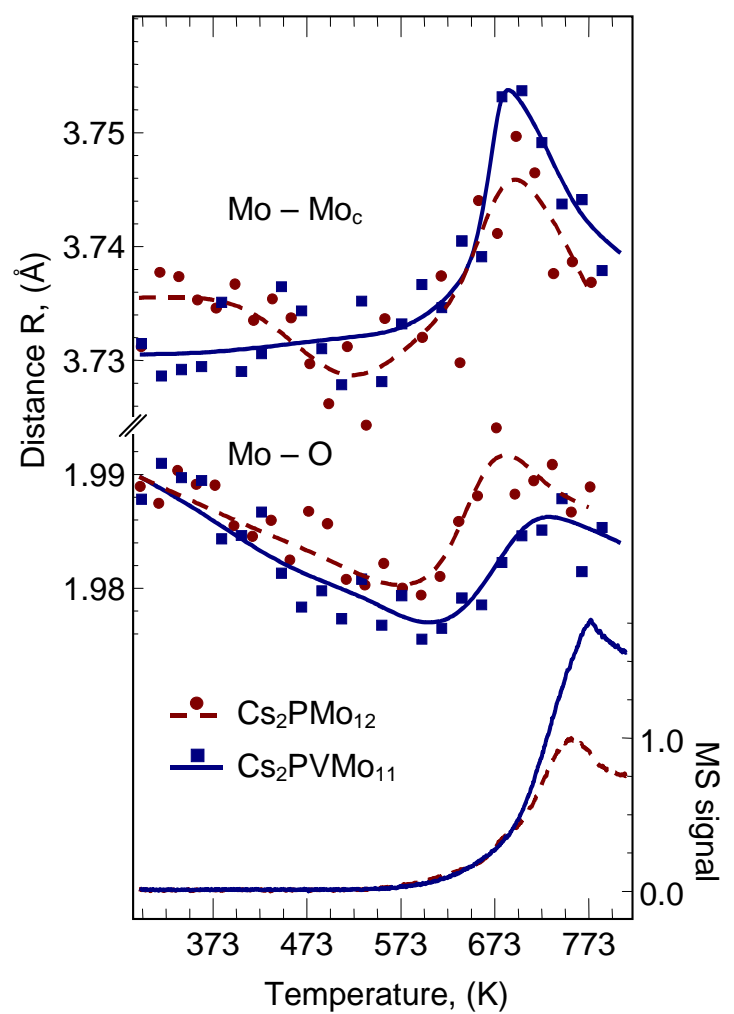

Figure 12: Evolution of representative $\mathrm{Mo}-\mathrm{O}$ and $\mathrm{Mo}-$ Mo distances in the average local structure around a Mo center in $\mathrm{Cs}_{2} \mathrm{H}_{2}\left[\mathrm{PVMo}_{11} \mathrm{O}_{40}\right]$ and $\mathrm{Cs}_{2} \mathrm{H}\left[\mathrm{PMo}_{12} \mathrm{O}_{40}\right]$ in $10 \%$ propene and $10 \%$ oxygen in He together with the normalized ion current of acrolein $(\mathrm{m} / \mathrm{e}=56)$.

\section{Stability and solid-state dynamics of $\mathrm{Mo}_{x}\left[\mathrm{PVMo}_{11-\mathrm{x}} \mathrm{O}_{40}\right]$ in propene and oxygen}

The stability and catalytic activity of cubic $\mathrm{Mo}_{\mathrm{x}}\left[\mathrm{PVMo}_{11-\mathrm{x}} \mathrm{O}_{40}\right]$ prepared from $\mathrm{H}_{4}\left[\mathrm{PVMo}_{11} \mathrm{O}_{40}\right] *$ $13 \mathrm{H}_{2} \mathrm{O}$ was investigated by subjecting the material to a temperature programmed reaction (TPR) experiment in 10 $\%$ propene and $10 \%$ oxygen in the temperature range from $300 \mathrm{~K}$ to $773 \mathrm{~K}$ in the in situ XRD set-up. The evolution of XRD patterns of $\mathrm{Mo}_{\mathrm{x}}\left[\mathrm{PVMo}_{11-\mathrm{x}} \mathrm{O}_{40}\right]$ measured during the thermal treatment is depicted in Figure $13 \mathrm{~A} . \mathrm{Mo}_{\mathrm{x}}\left[\mathrm{PVMo}_{11}\right.$ -
${ }_{\mathrm{x}} \mathrm{O}_{40}$ ] exhibits a remarkable stability up to temperatures of about $673 \mathrm{~K}$. At temperatures above $673 \mathrm{~K}$ slight changes to the pattern of $\mathrm{Mo}_{\mathrm{x}}\left[\mathrm{PVMo}_{11-\mathrm{x}} \mathrm{O}_{40}\right]$ can be observed together with the occurrence of additional peaks. The evolution of the ion current of acrolein $(\mathrm{m} / \mathrm{e}=56)$ during TPR of $\mathrm{Mo}_{\mathrm{x}}\left[\mathrm{PVMo}_{11-\mathrm{x}} \mathrm{O}_{40}\right]$ in propene and oxygen is shown in Figure 13B. Evidently, the onset of catalytic activity at $550 \mathrm{~K}$ does not correlate to significant changes in the longrange structure of $\mathrm{Mo}_{\mathrm{x}}\left[\mathrm{PVMo}_{11-\mathrm{x}} \mathrm{O}_{40}\right]$.
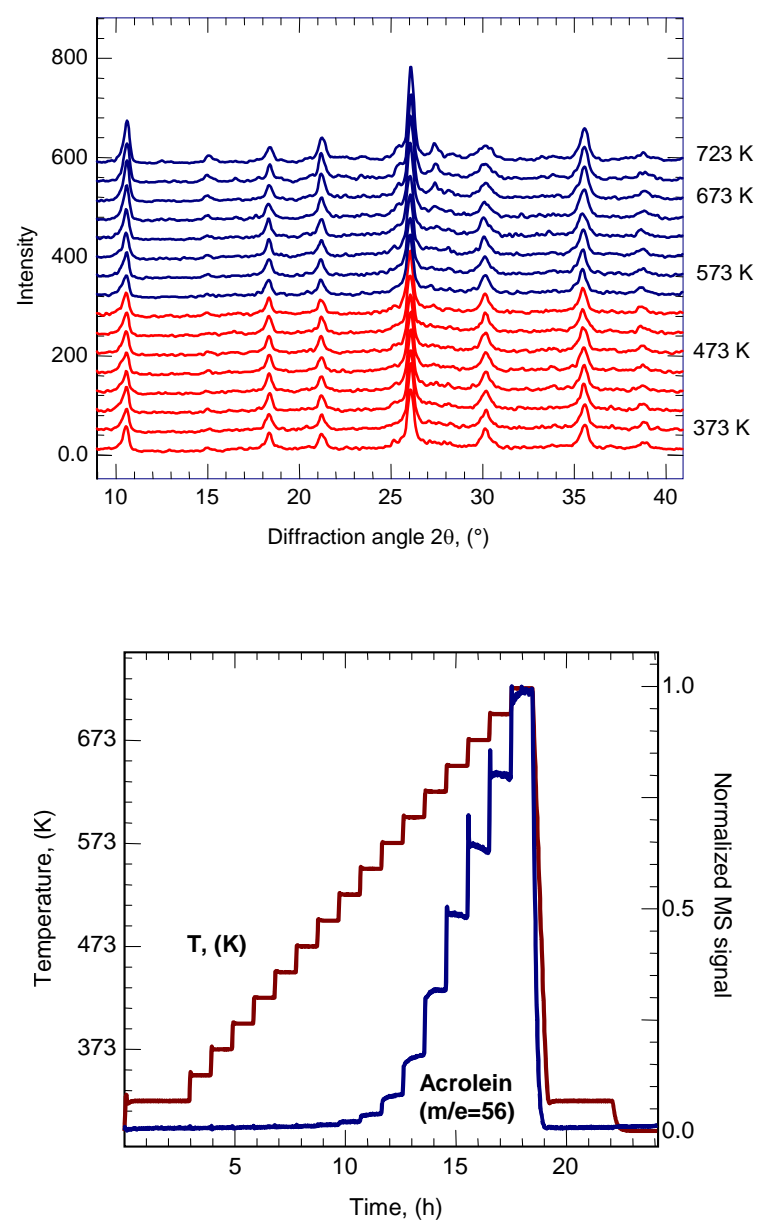

Figure 13: (A) Evolution of XRD patterns of $\mathrm{Mo}_{\mathrm{x}}\left[\mathrm{PVMo}_{11-\mathrm{x}} \mathrm{O}_{40}\right]$ during temperature programmed reaction of $10 \%$ propene and $10 \%$ oxygen in $\mathrm{He}$ in the range from $300 \mathrm{~K}$ to $773 \mathrm{~K}$. (B) Evolution of the normalized ion current of acrolein $(\mathrm{m} / \mathrm{e}=56)$ with reaction temperature.

Changes in the average local structure around the Mo centers in $\mathrm{Mo}_{\mathrm{x}}\left[\mathrm{PVMo}_{11-\mathrm{x}} \mathrm{O}_{40}\right]$ during temperature programmed reaction of $10 \%$ propene and $10 \%$ oxygen between $300 \mathrm{~K}$ and $723 \mathrm{~K}$ were determined by Mo K edge XAS measurements. Structural parameters were obtained from a refinement of a Keggin structure to the experimental spectra measured. The evolution of selected Mo-O distances in $\mathrm{Mo}_{\mathrm{x}}\left[\mathrm{PVMo}_{11-\mathrm{x}} \mathrm{O}_{40}\right]$ during TPR is depicted in Figure 14. The ion current of acrolein $(\mathrm{m} / \mathrm{e}=56)$ measured during TPR of $\mathrm{Mo}_{\mathrm{x}}\left[\mathrm{PVMo}_{11-\mathrm{x}} \mathrm{O}_{40}\right]$ exhibits an onset of catalytic activity at about $573 \mathrm{~K}$ accompanied by a characteristic decrease in the Mo - O distances shown. Subsequently, the temperature was held at $723 \mathrm{~K}$ and the gas phase was 
switched between reducing (propene) and oxidizing (propene and oxygen) atmosphere. It can be seen, that the local Mo structure can be reversibly changed from a reduced to an oxidized state of the catalytically active phase (Figure 14).

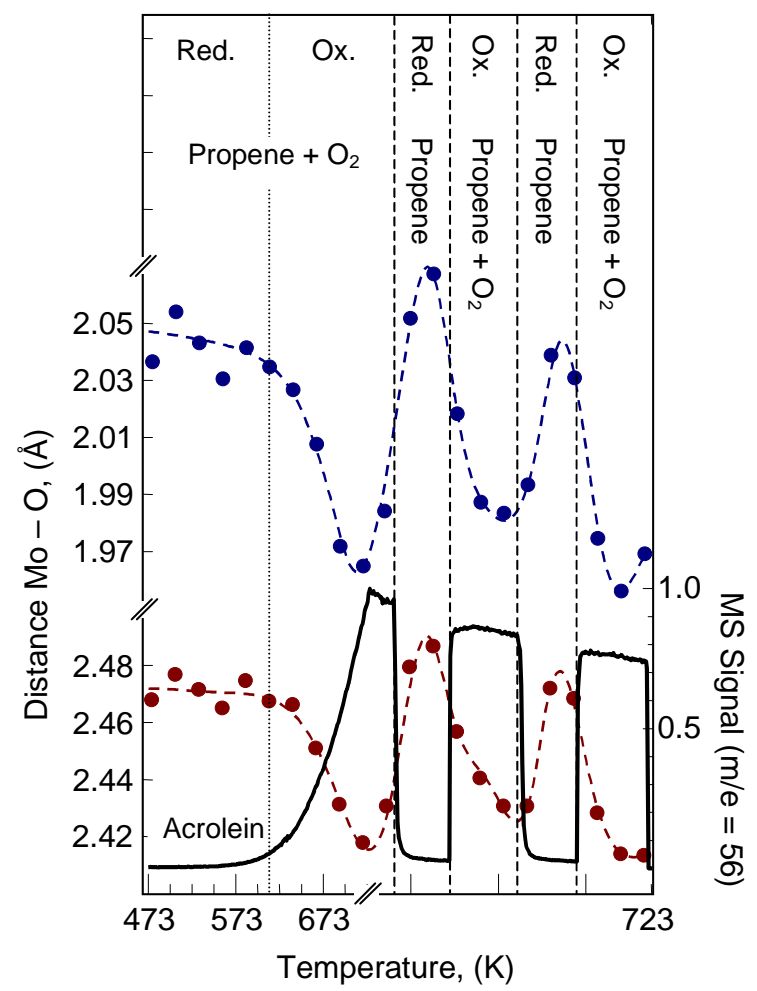

Figure 14: Evolution of selected Mo-O distances in the average local structure around a Mo center in $\mathrm{Mo}_{\mathrm{x}}\left[\mathrm{PVMo}_{11-}\right.$ $\left.{ }_{\mathrm{x}} \mathrm{O}_{40}\right]$ together with the normalized ion current of acrolein $(\mathrm{m} / \mathrm{e}=56)$ during temperature programmed reaction of 10 $\%$ propene and $10 \%$ oxygen in He from $373 \mathrm{~K}$ to $673 \mathrm{~K}$ followed by isothermal switching experiments between reducing (propene) and oxidizing (propene and oxygen) atmosphere. The reduced (Red.) or oxidized (Ox.) state of the active site depending on the reaction conditions is indicated.

\section{Discussion}

\section{Characterization of $\mathrm{H}_{4}\left[\mathrm{PVMo}_{11} \mathrm{O}_{40}\right]$ * $13 \mathrm{H}_{2} \mathrm{O}$}

In order to elucidate the evolution of the local structure around a $\mathrm{V}$ center in a mixed molybdenum oxide under reaction conditions, a heteropolyoxomolybdate $\mathrm{H}_{4}\left[\mathrm{PVMo}_{11} \mathrm{O}_{40}\right] * 13 \mathrm{H}_{2} \mathrm{O}$ with $\mathrm{V}$ centers substituting for Mo in the Keggin ion was prepared. Because some of the debate in the literature arises from the difficulties in comparing the various starting materials used, a rather detailed account of the preparation procedure employed and the structural characterization is provided. The long-range order structure of the as-prepared $\mathrm{H}_{4}\left[\mathrm{PVMo}_{11} \mathrm{O}_{40}\right] * 13 \mathrm{H}_{2} \mathrm{O}$ is similar to that of $\mathrm{H}_{3}\left[\mathrm{PMo}_{12} \mathrm{O}_{40}\right] * 13 \mathrm{H}_{2} \mathrm{O}$ (Figure 1) indicating that vanadium is indeed located in the Keggin ion. If
$\mathrm{V}$ was situated on extra-Keggin framework positions, the formation of the characteristic triclinic "13-hydrate" structure would not be expected. A vanadyl species located outside the Keggin ion will most likely result in the formation of a HPOM possessing a higher crystallographic symmetry (e.g. a cubic phase similar to the Cs salts of $\mathrm{H}_{3}\left[\mathrm{PMo}_{12} \mathrm{O}_{40}\right]$ * $13 \mathrm{H}_{2} \mathrm{O}$ ). Moreover, the local structure around the $\mathrm{V}$ centers in $\mathrm{H}_{4}\left[\mathrm{PVMo}_{11} \mathrm{O}_{40}\right] * 13 \mathrm{H}_{2} \mathrm{O}$ as determined by $\mathrm{V} \mathrm{K}$ edge XAS (Figure 4; Table 1) is in good agreement with a $\mathrm{V}$ site in the Keggin ion for the majority of vanadium in the material prepared Figure 5). The local average structure around the Mo centers in $\mathrm{H}_{4}\left[\mathrm{PVMo}_{11} \mathrm{O}_{40}\right] * 13 \mathrm{H}_{2} \mathrm{O}$ is hardly affected by the presence of $\mathrm{V}$ in the Keggin ion (Figure 3). The thermal stability of $\mathrm{H}_{4}\left[\mathrm{PVMo}_{11} \mathrm{O}_{40}\right] * 13$ $\mathrm{H}_{2} \mathrm{O}$ resembles the typical behavior of heteropolyoxomolybdates [21] during thermal treatment with a loss of crystal water at temperatures below $573 \mathrm{~K}$ and a loss of structural water above $573 \mathrm{~K}$ accompanied by partial decomposition of the Keggin ions. The endothermic loss of structural water at $\sim 573 \mathrm{~K}$ coincides with the onset of catalytic activity and characteristic structural changes during thermal activation of $\mathrm{H}_{4}\left[\mathrm{PVMo}_{11} \mathrm{O}_{40}\right] * 13 \mathrm{H}_{2} \mathrm{O}$ in propene, and propene and oxygen (Figure 11 and Figure 12).

\section{Thermal treatment of $\mathrm{H}_{4}\left[\mathrm{PVMo}_{11} \mathrm{O}_{40}\right] * 13 \mathrm{H}_{2} \mathrm{O}$ in pro- pene}

Previously, we have reported the formation of a cubic HPOM from $\mathrm{H}_{3}\left[\mathrm{PMo}_{12} \mathrm{O}_{40}\right] * 13 \mathrm{H}_{2} \mathrm{O}$ by thermal treatment in propene in the temperature range from $300 \mathrm{~K}$ to 773 K. [9] The cubic HPOM (i.e. $\mathrm{Mo}_{\mathrm{x}}\left[\mathrm{PMo}_{12-\mathrm{x}} \mathrm{O}_{40}\right]$ ) obtained is characterized by Mo centers on extra-Keggin framework positions (Figure 7B) and a superior catalytic activity in propene oxidation compared to the as-prepared HPOM. Furthermore, the onset-temperature for the formation of the cubic HPOM coincided with the onset of catalytic activity at $\sim 573 \mathrm{~K}$. Evidently, a similar cubic HPOM (i.e. $\mathrm{Mo}_{\mathrm{x}}\left[\mathrm{PVMo}_{11-\mathrm{x}} \mathrm{O}_{40}\right]$ ) can be obtained from the thermal treatment of $\mathrm{H}_{4}\left[\mathrm{PVMo}_{11} \mathrm{O}_{40}\right] * 13 \mathrm{H}_{2} \mathrm{O}$ in propene exhibiting a long range ordered structure comparable to that of the cubic HPOM obtained from $\mathrm{H}_{3}\left[\mathrm{PMo}_{12} \mathrm{O}_{40}\right] * 13 \mathrm{H}_{2} \mathrm{O}$ (Figure 6, Figure 7, Table 2 [9]). If during treatment of $\mathrm{H}_{4}\left[\mathrm{PVMo}_{11} \mathrm{O}_{40}\right] * 13 \mathrm{H}_{2} \mathrm{O}$ vanadium migrated on extraKeggin framework positions instead of Mo, such a good agreement of the XRD patterns of the two cubic phases would not be expected. In total, a site occupancy of $\sim 0.15$ Table 2) together with 12 suitable extra-Keggin sites, and two Keggin ions per unit cell amounts to about one extraKeggin molybdenum center per Keggin ion (1.8 per two Keggin ions). Conversely, with $\mathrm{V}$ present on an extraKeggin framework position a site occupancy of $\sim 0.3$ would amount to about two vanadium centers per Keggin ions which exceeds the number of $\mathrm{V}$ centers available in $\mathrm{H}_{4}\left[\mathrm{PVMo}_{11} \mathrm{O}_{40}\right] * 13 \mathrm{H}_{2} \mathrm{O}$. In addition to the structural similarity of the cubic phases obtained from thermal treatment of $\mathrm{H}_{3}\left[\mathrm{PMo}_{12} \mathrm{O}_{40}\right] * 13 \mathrm{H}_{2} \mathrm{O}$ and $\mathrm{H}_{4}\left[\mathrm{PVMo}_{11} \mathrm{O}_{40}\right] * 13 \mathrm{H}_{2} \mathrm{O}$, the average local structure around the Mo centers in a $\mathrm{V}$ 
containing Keggin ion and a $\mathrm{V}$ free Keggin ion evolves similarly during treatment in propene (Figure 8 ). The onset of the structural changes in the Keggin ion at $\sim 573 \mathrm{~K}$ is again correlated to the characteristic weakening of the Mo$\mathrm{O}$ bond detectable in various molybdenum oxides $[29,30]$ which in turn coincides with the onset of catalytic activity. Both do not seem to be effected by the presence of $\mathrm{V}$ in the Keggin ions of $\mathrm{H}_{4}\left[\mathrm{PVMo}_{11} \mathrm{O}_{40}\right] * 13 \mathrm{H}_{2} \mathrm{O}$.

The good agreement between the experimental XRD patterns of the two cubic phases in Figure 6 and the corresponding structural data given in Table 2 are, however, only indirect evidences for the $\mathrm{V}$ centers residing in the lacunary Keggin ions of the cubic HPOM obtained from $\mathrm{H}_{4}\left[\mathrm{PVMo}_{11} \mathrm{O}_{40}\right] * 13 \mathrm{H}_{2} \mathrm{O}$. Therefore, element specific Xray absorption spectroscopy was employed to determine the average valence and the local structure around the $\mathrm{V}$ center. From an analysis of the V K near-edge spectra [31] it is evident, that the $\mathrm{V}$ is present as $\mathrm{V}^{5+}$ in the Keggin ion of asprepared $\mathrm{H}_{4}\left[\mathrm{PVMo}_{11} \mathrm{O}_{40}\right] * 13 \mathrm{H}_{2} \mathrm{O}$ and is reduced from $\mathrm{V}^{5+}$ to $\mathrm{V}^{4+}$ during thermal activation and formation of the cubic HPOM. [32] The detailed local structure of the vanadium in cubic $\mathrm{Mo}_{\mathrm{x}}\left[\mathrm{PVMo}_{11-\mathrm{x}} \mathrm{O}_{40}\right]$ was obtained from an analysis of the V K edge EXAFS spectra (Figure 4). The experimental $\mathrm{FT}\left(\chi(\mathrm{k})^{*} \mathrm{k}^{3}\right)$ of cubic $\mathrm{Mo}_{\mathrm{x}}\left[\mathrm{PVMo}_{11-\mathrm{x}} \mathrm{O}_{40}\right]$ obtained from $\mathrm{H}_{4}\left[\mathrm{PVMo}_{11} \mathrm{O}_{40}\right] * 13 \mathrm{H}_{2} \mathrm{O}$ is in good agreement with the theoretical XAFS calculation assuming that $\mathrm{V}$ is still situated on a Mo site in the Keggin ion (Figure 4.II). Both the $\mathrm{V}-\mathrm{O}$ and $\mathrm{V}-\mathrm{Mo}$ distances and the corresponding DebyeWaller factors deviate only slightly from those of asprepared $\mathrm{H}_{4}\left[\mathrm{PVMo}_{11} \mathrm{O}_{40}\right] * 13 \mathrm{H}_{2} \mathrm{O}$ (Table 1). These deviations result mostly from the local structural changes caused by the reduction of the vanadium and the partial decomposition of the Keggin ion. The close relationship of the medium range-order around the $\mathrm{V}$ center in both $\mathrm{H}_{4}\left[\mathrm{PVMo}_{11} \mathrm{O}_{40}\right] * 13 \mathrm{H}_{2} \mathrm{O}$ and $\mathrm{Mo}_{\mathrm{x}}\left[\mathrm{PVMo}_{11-\mathrm{x}} \mathrm{O}_{40}\right]$ is also evident from the very similar amplitude and imaginary part in their corresponding $\mathrm{FT}\left(\chi(\mathrm{k}) * \mathrm{k}^{3}\right)$ above $3.5 \AA$ which includes the characteristic V-Mo distances inside the Keggin ion.

With the otherwise very good agreement between theory and experiment, the considerable deviation at about $2.8 \AA$ in the $\mathrm{FT}\left(\chi(\mathrm{k}) * \mathrm{k}^{3}\right.$ ) of $\mathrm{Mo}_{\mathrm{x}}\left[\mathrm{PVMo}_{11-\mathrm{x}} \mathrm{O}_{40}\right]$ (Figure 4.II) and in the comparison between $\mathrm{H}_{4}\left[\mathrm{PVMo}_{11} \mathrm{O}_{40}\right]$ * $13 \mathrm{H}_{2} \mathrm{O}$ and $\mathrm{Mo}_{\mathrm{x}}\left[\mathrm{PVMo}_{11-\mathrm{x}} \mathrm{O}_{40}\right]$ (Figure 10) is particularly prominent. As can be seen from Figure 4.III, the agreement between theory and experiment can be significantly improved be considering an additional Mo center with a $\mathrm{V}-$ Mo distance of $\sim 2.8 \AA$ (D in Figure 4.IV, Table 1). This distance corresponds very well to the distance from a $\mathrm{V}$ center in a Keggin ion to a Mo center on an extra-Keggin position according to the structural data determined by the XRD refinement to the pattern of $\mathrm{Mo}_{\mathrm{x}}\left[\mathrm{PVMo}_{11-\mathrm{x}} \mathrm{O}_{40}\right]$ (Figure 7A, Table 2). [9, 17, 18] A schematic representation of the local structure around the $\mathrm{V}$ center in activated cubic $\mathrm{Mo}_{\mathrm{x}}\left[\mathrm{PVMo}_{11-\mathrm{x}} \mathrm{O}_{40}\right]$ is depicted in Figure 15. The structure of the partial Keggin ion shown corresponds to the data given in Table 2 while the $\mathrm{V}-\mathrm{O}$ and $\mathrm{V}-\mathrm{Mo}$ distances indicated are obtained from a structure refinement to the $\mathrm{V} \mathrm{K}$ edge data (Table 1). A-D indicate V-Mo distances corresponding to the $\mathrm{FT}\left(\chi(\mathrm{k}) * \mathrm{k}^{3}\right)$ in Figure 4(IV.).

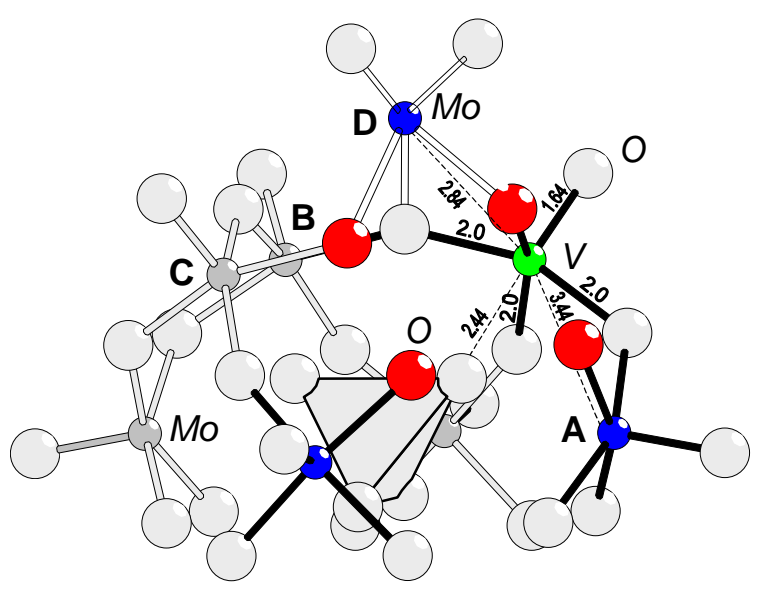

Figure 15: Schematic representation of the local structure around the $\mathrm{V}$ center in activated cubic $\mathrm{Mo}_{\mathrm{x}}\left[\mathrm{PVMo}_{11-\mathrm{x}} \mathrm{O}_{40}\right]$. The upper half of the Keggin ion shown corresponds to the structural data given in Table 2. V-O and V-Mo distances indicated are obtained from a structure refinement to the $\mathrm{V}$ $\mathrm{K}$ edge data (Table 1). A-D indicate V-Mo distances corresponding to the $\mathrm{FT}\left(\chi(\mathrm{k}) * \mathrm{k}^{3}\right)$ in Figure 4(IV.).

A Mo center at a distance of $2.8 \AA$ from the $\mathrm{V}$ center in the Keggin ion confirms the migration of metal centers out of the Keggin ion onto extra-Keggin framework position during thermal treatment of $\mathrm{H}_{4}\left[\mathrm{PVMo}_{11} \mathrm{O}_{40}\right] * 13 \mathrm{H}_{2} \mathrm{O}$ in propene. Together with the good agreement between the experimental data and the calculated EXAFS function based on a structural model with $\mathrm{V}$ in the Keggin ion, this clearly shows that indeed Mo migrates onto an extraKeggin site. A V - Mo distance of $\sim 2.8 \AA$ is only slightly longer than the metal-metal distance in Mo metal ( $2.73 \AA)$ or V metal $(2.62 \AA)$. This short distance should have a pronounced influence on the catalytic properties of the active site of $\mathrm{H}_{4}\left[\mathrm{PVMo}_{11} \mathrm{O}_{40}\right] * 13 \mathrm{H}_{2} \mathrm{O}$ under reaction conditions, possibly on its capability to activate oxygen during the transition from the reduced form to the oxidized form. The coordination number of 0.6 determined for the V-Mo distance of $\sim 2.8 \AA$ indicates either that not all Keggin ions exhibit a partial decomposition or that the $\mathrm{V}$ center in the lacunary Keggin ion is not always located in the vicinity of the extra-framework molybdenum. The former appears to be corroborated by the occupancy factor of the extraKeggin site given in Table $2(\sim 0.9$ Mo centers per Keggin ion).

The experimental data shown indicate that similar to $\mathrm{H}_{3}\left[\mathrm{PMo}_{12} \mathrm{O}_{40}\right] * 13 \mathrm{H}_{2} \mathrm{O}$ molybdenum centers migrate out of the Keggin ions of $\mathrm{H}_{4}\left[\mathrm{PVMo}_{11} \mathrm{O}_{40}\right] * 13 \mathrm{H}_{2} \mathrm{O}$ onto extraKeggin sites, while vanadium centers remain as $\mathrm{V}^{4+}$ in the partially decomposed lacunary Keggin ions of $\mathrm{Mo}_{\mathrm{x}}\left[\mathrm{PVMo}_{11-\mathrm{x}} \mathrm{O}_{40}\right]$. In contrast to corresponding reports in the literature, thermal activation of $\mathrm{H}_{4}\left[\mathrm{PVMo}_{11} \mathrm{O}_{40}\right]$ * $13 \mathrm{H}_{2} \mathrm{O}$ does not result in the majority of vanadium centers located on extra-Keggin sites. Because in contrast to the 
treatment of $\mathrm{H}_{3}\left[\mathrm{PMo}_{12} \mathrm{O}_{40}\right] * 13 \mathrm{H}_{2} \mathrm{O}$, a cubic phase stabilized by extra-Keggin metal centers can be readily obtained by a thermal treatment of $\mathrm{H}_{4}\left[\mathrm{PVMo}_{11} \mathrm{O}_{40}\right] * 13 \mathrm{H}_{2} \mathrm{O}$ it has been concluded that $\mathrm{V}$ centers have to migrate out off the Keggin ion. [12] However, as we have previously demonstrated, a cubic HPOM with an X-ray diffraction pattern very similar to that of the cubic HPOM obtained from $\mathrm{H}_{4}\left[\mathrm{PVMo}_{11} \mathrm{O}_{40}\right] * 13 \mathrm{H}_{2} \mathrm{O}$ can be prepared by thermal treatment of $\mathrm{H}_{3}\left[\mathrm{PMo}_{12} \mathrm{O}_{40}\right] * 13 \mathrm{H}_{2} \mathrm{O}$. [9] Hence, vanadium as an addenda substituent in the Keggin ion is not a prerequisite for the formation of a cubic HPOM. Based on NMR and ESR data of a thermally treated V containing HPOM, Pöppl et al. suggested that $\mathrm{V}$ is situated on extra-Keggin sites. [38] However, from their NMR/ESR measurements the authors also report that already in the starting material used vanadium centers are located outside the Keggin ions. Unfortunately, no further structural characterization of the vanadium containing HPOM used is provided. Assuming that the authors did indeed prepare a vanadyl salt of $\mathrm{H}_{3}\left[\mathrm{PMo}_{12} \mathrm{O}_{40}\right] * 13 \mathrm{H}_{2} \mathrm{O}$ (e.g. (VO) $\left[\mathrm{PMo}_{12} \mathrm{O}_{40}\right]$ ), the location of the $\mathrm{V}$ centers outside the Keggin ion in the thermally treated material is not surprising. However, the objective of the work presented here clearly was to study the influence of $\mathrm{V}$ centers substituting for Mo in regular molybdenum oxide on structure-activity correlations. This can only be achieved by investigating the structural evolution of $\mathrm{H}_{4}\left[\mathrm{PVMo}_{11} \mathrm{O}_{40}\right] * 13 \mathrm{H}_{2} \mathrm{O}$ under reaction conditions instead of that of $(\mathrm{VO})\left[\mathrm{PMo}_{12} \mathrm{O}_{40}\right]$.

The $\mathrm{V} \quad \mathrm{K}$ near-edge regions of as-prepared $\mathrm{Cs}_{2} \mathrm{H}_{2}\left[\mathrm{PVMo}_{11} \mathrm{O}_{40}\right]$ and the thermally activated $\mathrm{Cs}_{2} \mathrm{Mo}_{\mathrm{x}}\left[\mathrm{PVMo}_{11-\mathrm{x}} \mathrm{O}_{40}\right]$ (not shown) are very similar to those measured for $\mathrm{H}_{4}\left[\mathrm{PVMo}_{11} \mathrm{O}_{40}\right] * 13 \mathrm{H}_{2} \mathrm{O}$ and $\mathrm{Mo}_{\mathrm{x}}\left[\mathrm{PVMo}_{11-\mathrm{x}} \mathrm{O}_{40}\right]$. This indicates a comparable local structure around the $\mathrm{V}$ centers in the Cs compounds (i.e. $\mathrm{V}$ located in the Keggin ion). However, because of the overlapping V K and Cs L edges no detailed EXAFS analysis can be performed. The Cs $\mathrm{L}$ edge spectra measured of the as-prepared $\mathrm{Cs}_{2} \mathrm{H}_{2}\left[\mathrm{PVMo}_{11} \mathrm{O}_{40}\right]$ and the thermally activated $\mathrm{Cs}_{2} \mathrm{Mo}_{\mathrm{x}}\left[\mathrm{PVMo}_{11-\mathrm{x}} \mathrm{O}_{40}\right]$ show no significant differences. This indicates, that the void between the Keggin ions in $\mathrm{Cs}_{2} \mathrm{H}_{2}\left[\mathrm{PVMo}_{11} \mathrm{O}_{40}\right]$ is entirely filled by the Cs cations and, hence, no migration of Mo into the close vicinity of the Cs ions is detectable. Hence, the stabilizing effect of Cs cations on the structural integrity of HPOM results from the occupation of extra-Keggin sites which otherwise would be available for the migration of molybdenum centers out of the Keggin ions. This holds for the stabilizing effect of Cs in both $\mathrm{H}_{3}\left[\mathrm{PMo}_{12} \mathrm{O}_{40}\right] * 13 \mathrm{H}_{2} \mathrm{O}$ and $\mathrm{H}_{4}\left[\mathrm{PVMo}_{11} \mathrm{O}_{40}\right] *$ $13 \mathrm{H}_{2} \mathrm{O}$. Accordingly, the slow deactivation of heteropolyoxomolybdates under partial oxidation reaction conditions can be explained by the absence of this stabilization and, thus, the formation of interconnected species and, eventually, $\mathrm{MoO}_{3}$ during thermal treatment.

\section{Thermal activation of $\mathrm{H}_{4}\left[\mathrm{PVMO}_{11} \mathrm{O}_{40}\right]$ * $13 \mathrm{H}_{2} \mathrm{O}$ in pro- pene and oxygen}

The structural changes observed in $\mathrm{H}_{4}\left[\mathrm{PVMo}_{11} \mathrm{O}_{40}\right]$ * $13 \mathrm{H}_{2} \mathrm{O}$ during activation in propene and oxygen indicate a partial reduction (Figure 11) and partial decomposition of the Keggin ions (Figure 12) similar to the structural evolution during treatment of $\mathrm{H}_{4}\left[\mathrm{PVMo}_{11} \mathrm{O}_{40}\right] * 13 \mathrm{H}_{2} \mathrm{O}$ in propene (Figure 8). Apparently, the onset of the formation of a lacunary Keggin ion and the migration of Mo centers is correlated to the onset of catalytic activity. Similar to the structural behavior of $\mathrm{H}_{3}\left[\mathrm{PMo}_{12} \mathrm{O}_{40}\right]$ * $13 \mathrm{H}_{2} \mathrm{O}$ under reaction conditions, [9] a partial decomposition and formation of lacunary Keggin ions from $\mathrm{H}_{4}\left[\mathrm{PVMo}_{11} \mathrm{O}_{40}\right] * 13 \mathrm{H}_{2} \mathrm{O}$ is a prerequisite for the material to become an active partial oxidation catalyst. The genuine Mo site in the intact Keggin ion as it is present in the thermally stable $\mathrm{Cs}_{3}\left[\mathrm{PMo}_{12} \mathrm{O}_{40}\right]$ under propene and oxygen at $673 \mathrm{~K}$ is catalytically inactive. [9] Only the partial decomposition of the Keggin ion and subsequent migration of molybdenum on vacant extraKeggin sites turns the precursor Keggin ion in the HPOM into an active partial oxidation catalyst. While the amplitude of the structural changes in the Keggin ion under reaction conditions is very similar for $\mathrm{H}_{4}\left[\mathrm{PVMo}_{11} \mathrm{O}_{40}\right] * 13 \mathrm{H}_{2} \mathrm{O}$ and $\mathrm{H}_{3}\left[\mathrm{PMo}_{12} \mathrm{O}_{40}\right] * 13 \mathrm{H}_{2} \mathrm{O}$ (Figure 12), the evolution of the electronic structure suggests a more pronounced reduction of the average Mo valence in $\mathrm{H}_{4}\left[\mathrm{PVMo}_{11} \mathrm{O}_{40}\right] * 13 \mathrm{H}_{2} \mathrm{O}$ compared to $\mathrm{H}_{3}\left[\mathrm{PMo}_{12} \mathrm{O}_{40}\right] * 13 \mathrm{H}_{2} \mathrm{O}$. Hence, in addition to a possible structure promoting effect of $\mathrm{V}$ centers in molybdenum based oxides, the amount of Mo centers with an average valence less than six appears to be increased in $\mathrm{V}$ containing molybdenum oxides during activation in propene and oxygen. The latter seems to correlate with the improved catalytic activity observed (Figure 12).

The catalytic activity and stability of the cubic $\mathrm{Mo}_{\mathrm{x}}\left[\mathrm{PVMo}_{11-\mathrm{x}} \mathrm{O}_{40}\right]$ phase obtained from $\mathrm{H}_{4}\left[\mathrm{PVMo}_{11} \mathrm{O}_{40}\right]$ * $13 \mathrm{H}_{2} \mathrm{O}$ was investigated by in situ XRD and XAS under propene oxidation conditions. It can be seen from Figure 13 that the long-range order structure of the cubic phase persists to about $620 \mathrm{~K}$ in propene and oxygen. This structural stability under reaction conditions is unusual for asprepared HPOM, which tend to exhibit several transitions and decompositions during thermal treatment. The onset of catalytic activity of the cubic phase at about $573 \mathrm{~K}$ (Figure $13 \mathrm{~B}$ ) is not accompanied by detectable changes in the longrange order structure. Both the stability under reaction conditions and the structural invariance at the onset of catalytic activity indicate that the structure of the cubic $\mathrm{Mo}_{\mathrm{x}}\left[\mathrm{PVMo}_{11-\mathrm{x}} \mathrm{O}_{40}\right]$ is closely related to the structure of the active phase of $\mathrm{H}_{4}\left[\mathrm{PVMo}_{11} \mathrm{O}_{40}\right] * 13 \mathrm{H}_{2} \mathrm{O}$. At temperatures above $\sim 650 \mathrm{~K}$ the cubic phase exhibits a change in the relative ratio of the diffraction peaks around $20^{\circ}$ and the occurrence of additional peaks indicating the formation of an unidentified phase at elevated temperature. The modified cubic phase present above $650 \mathrm{~K}$ can still be simulated by the structure displayed in Figure 7B, while a slightly elongated distance of the extra-Keggin Mo center from the Keggin ion can account for the modified peak ratio. 
In contrast to the invariance of the long-range structure of $\mathrm{Mo}_{\mathrm{x}}\left[\mathrm{PVMo}_{11-\mathrm{x}} \mathrm{O}_{40}\right]$ under reaction conditions, the short-range structure of the Keggin ion as detected by in situ XAS exhibits pronounced changes that correlate with the onset of catalytic activity at $\sim 573 \mathrm{~K}$. The structural changes observed are in the order of $\sim 5 \%$ pointing towards a "fine tuning" of the $\mathrm{Mo}-\mathrm{O}$ distances possibly accompanying the uptake of oxygen and the transition from the reduced form of the active phase to the oxidized form under reaction conditions. The resulting active site of these catalysts consists of an extra-framework molybdenum center that forms an oxo cluster together with the lacunary Keggin ion presenting a coordinatively unsaturated metal center to the gas phase embedded in a matrix of stable terminal oxygen atoms (Figure 15). The remaining hole in the lacunary Keggin ion permits adsorbed substrate molecules to access the bridging oxygen atoms in the vicinity of the Mo center. As can be seen from the correlation between local structural changes and the gas phase composition in Figure 14, the structural state of the reduced form of $\mathrm{Mo}_{\mathrm{x}}\left[\mathrm{PVMo}_{11-\mathrm{x}} \mathrm{O}_{40}\right]$ can be reversibly altered by changing the gas phase composition from propene and oxygen to propene. Apparently, at temperatures above $\sim 600 \mathrm{~K}$ the oxygen coordinated to the active site of $\mathrm{Mo}_{\mathrm{x}}\left[\mathrm{PVMo}_{11-\mathrm{x}} \mathrm{O}_{40}\right]$ can be easily exchanged and can participate in partial oxidation reactions, possibly according to a simple LangmuirHinshelwood mechanism. Future V K edge XAFS investigations will be based on the established structural evolution of $\mathrm{H}_{4}\left[\mathrm{PVMo}_{11} \mathrm{O}_{40}\right] * 13 \mathrm{H}_{2} \mathrm{O}$ during thermal activation and the detailed local coordination of the $\mathrm{V}$ centers in the resulting cubic $\mathrm{Mo}_{\mathrm{x}}\left[\mathrm{PVMo}_{11-\mathrm{x}} \mathrm{O}_{40}\right]$, in order to reveal the dynamic behavior of the active site under varying reaction conditions.

Implication of $V$ centers in molybdenum oxide based catalysts for structure-activity relationships

The investigations presented indicate, that HPOM are indeed suitable three-dimensional model system to investigate the directing effect of metal centers on the structural evolution of molybdenum oxides during thermal treatment. However, similar to the behavior of $\mathrm{H}_{3}\left[\mathrm{PMo}_{12} \mathrm{O}_{40}\right] * 13$ $\mathrm{H}_{2} \mathrm{O}$, the original structure of as-prepared $\mathrm{H}_{4}\left[\mathrm{PVMo}_{11} \mathrm{O}_{40}\right]$ * $13 \mathrm{H}_{2} \mathrm{O}$ does not correspond to the structure of the material under reaction conditions. Instead, $\mathrm{H}_{4}\left[\mathrm{PVMo}_{11} \mathrm{O}_{40}\right]$ * $13 \mathrm{H}_{2} \mathrm{O}$ should be regarded as the precursor of the catalytically active phase. The onset temperature of catalytic activity of $\mathrm{H}_{4}\left[\mathrm{PVMo}_{11} \mathrm{O}_{40}\right] * 13 \mathrm{H}_{2} \mathrm{O}$ at $\sim 573 \mathrm{~K}$ is in good agreement with that of $\mathrm{H}_{3}\left[\mathrm{PMo}_{12} \mathrm{O}_{40}\right] * 13 \mathrm{H}_{2} \mathrm{O}, \mathrm{MoO}_{3}$, $(\mathrm{Mo}, \mathrm{V})_{5} \mathrm{O}_{14}$, and other mixed metal oxides (e.g. $\mathrm{MoVNbTeO}_{\mathrm{x}}$ ) indicating the formation of similar active sites on these materials under reaction conditions. The incorporation of $\mathrm{V}$ centers in the Keggin ion does not cause a pronounced destabilization of the Keggin ion and an accelerated decomposition at elevated temperatures. Apparently, vanadium centers are quite stable in the lacunary Keggin ion of $\mathrm{Mo}_{\mathrm{x}}\left[\mathrm{PVMo}_{11-\mathrm{x}} \mathrm{O}_{40}\right]$ that forms under reaction condi- tions. Moreover, $\mathrm{V}$ centers can change their oxidation state from $\mathrm{V}^{5+}$ to $\mathrm{V}^{4+}$ without a significant destabilization of the lacunary Keggin ion detectable. The capability of $\mathrm{V}$ centers to substitute for Mo in as-prepared Keggin type HPOM as well as thermally activated HPOM may be explained by the similar ion radii of $\mathrm{V}^{5+}(68 \mathrm{pm})$ and $\mathrm{V}^{4+}(72 \mathrm{pm})$ compared to $\mathrm{Mo}^{6+}(74 \mathrm{pm})$ in a six-fold coordination. [34] This is in contrast to the incorporation of larger $\mathrm{Nb}$ centers in HPOM, which result in a pronounced destabilization of the Keggin ion. [35] Hence, vanadium may act as a structural promoter in the catalyst precursor facilitating the formation of the active (Mo, V) oxide phase. In addition to act as a structural promoter, the structural flexibility and redox capability of the vanadium centers may facilitate a direct participation of $\mathrm{V}$ in the activation of gas phase oxygen and propene on the active site of $\mathrm{Mo}_{\mathrm{x}}\left[\mathrm{PVMo}_{11-\mathrm{x}} \mathrm{O}_{40}\right]$. The detailed investigations of the local structure of vanadium in $\mathrm{Mo}_{\mathrm{x}}\left[\mathrm{PVMo}_{11-\mathrm{x}} \mathrm{O}_{40}\right]$ presented here, permit for the first time to propose a model for the characteristic geometric structure of the active site in Mo and $\mathrm{V}$ containing metal oxide catalysts (Figure 15). This structure deviates significantly from the structure of the as-prepared materials and could have by no means inferred from it. In situ investigations are indispensable to elucidate the "real structure" of a working catalyst under reaction conditions. Obviously, structureactivity correlations deduced from the ideal crystallographic structure of more complex Mo and V containing mixed oxide catalysts have to be carefully validated by in situ bulk structural investigations.

\section{Conclusions}

The bulk structural evolution of $\mathrm{H}_{4}\left[\mathrm{PVMo}_{11} \mathrm{O}_{40}\right] * 13$ $\mathrm{H}_{2} \mathrm{O}$ under reducing (propene) and partial oxidation reaction conditions (propene and oxygen) was studied by in situ XRD and XAS. During treatment in propene, the loss of crystal water in the temperature range from $373 \mathrm{~K}$ to $573 \mathrm{~K}$ is followed by a partial decomposition, reduction of the average Mo valence, and formation of a characteristic cubic $\mathrm{HPOM}\left(\mathrm{Mo}_{\mathrm{x}}\left[\mathrm{PVMo}_{11-\mathrm{x}} \mathrm{O}_{40}\right]\right)$ at $573 \mathrm{~K}$. This behavior is similar to the structural evolution of $\mathrm{H}_{3}\left[\mathrm{PMo}_{12} \mathrm{O}_{40}\right] * 13$ $\mathrm{H}_{2} \mathrm{O}$ during treatment in propene. The formation of cubic $\mathrm{Mo}_{\mathrm{x}}\left[\mathrm{PVMo}_{11-\mathrm{x}} \mathrm{O}_{40}\right]$ with Mo centers on extra Keggin framework positions and $\mathrm{V}$ centers remaining in the lacunary Keggin ions coincides with the onset of catalytic activity at $\sim 573 \mathrm{~K}$. The detailed investigations of the local structure of vanadium in $\mathrm{Mo}_{\mathrm{x}}\left[\mathrm{PVMo}_{11-\mathrm{x}} \mathrm{O}_{40}\right]$ presented permit to propose a model for the geometric structure of the active site in Mo and $\mathrm{V}$ containing metal oxide catalysts. The cubic $\mathrm{Mo}_{\mathrm{x}}\left[\mathrm{PVMo}_{11-\mathrm{x}} \mathrm{O}_{40}\right]$ phase prepared from $\mathrm{H}_{4}\left[\mathrm{PVMo}_{11} \mathrm{O}_{40}\right] * 13 \mathrm{H}_{2} \mathrm{O}$ is stable in propene and oxygen up to $\sim 620 \mathrm{~K}$ and exhibits an onset of activity at $\sim 573 \mathrm{~K}$. This onset of activity is correlated to characteristic changes in the average local Mo structure indicating a reversible transition from the reduced state of the active site in $\mathrm{Mo}_{\mathrm{x}}\left[\mathrm{PVMo}_{11 \mathrm{x}} \mathrm{O}_{40}\right]$ to an oxidized state under propene oxidation reaction conditions. 


\section{Acknowledgements}

We are grateful to the Hamburger Synchrotronstrahlungslabor, HASYLAB, and the European Synchrotron Radiation Facility, ESRF, for providing beamtime for the work described. R.E. Jentoft is acknowledged for par- ticipating in the XAS measurements. Prof. R. Schlögl is acknowledged for his continuous support.

\section{References}

[1] M.M. Lin, Appl. Catal. A: General 207 (2001) 1.

[2] P. DeSanto Jr., D.J. Buttrey, R.K. Grasselli, C.G. Lugmair, A.F. Volpe, B.H. Toby, T. Vogt, Topics in Catalysis 23 (2003) 23.

[3] T. Okuhara, N. Mizuno, M. Misono, Advances in Catalysis 41 (1996) 113.

[4] J.H. Holles, C.J. Dillon, J.A. Labinger, M.E. Davis, J. Catal. 218 (2003) 42 ; J.H. Holles, C.J. Dillon, J.A. Labinger, M.E. Davis, J. Catal. 218 (2003) 54.

[5] J.B. Moffat, Metal-Oxygen Cluster: The Surface and Catalytic Properties of Heteropolyoxometalates, Kluwer Academic/Plenum, New York (2001)

[6] J.J. Borras-Almenar, E. Coronado, A. Muller, M.T. Pope (Eds.), Polyoxometalate Molecular Science, Kluwer, Dordrecht, The Netherlands (2003).

[7] O. Watzenberger, G. Emig, D. T. Lynch, J. Catal. 124 (1990) 247.

[8] K.E. Lee, J. Melsheimer, S. Berndt, G. Mestl, R. Schlögl, K. Köhler, Appl. Catal. A: General 214 (2001) 125.

[9] J. Wienold, O. Timpe, T. Ressler, Chemistry, A European Journal 9 (2003) 6007.

[10] C. Marchal-Roch, N. Laronze, N. Guilou, A. Teze, G. Herve, Appl. Catal. A: General 199 (2000) 33.

[11] C. Marchal-Roch, R. Bayer, J. F. Moisan, A. Teze, G. Herve, Topics in Catalysis 3 (1996) 407.

[12] T. Ilkenhans, B. Herzog, T. Braun, R. Schlögl, J. Catal. 153 (1995) 275.

[13] C. Marchal-Roch, J.-M.M. Millet, C.R. Acad. Sci. C4 (2001) 321.

[14] G. Centi, V. Lena, F. Trifiro, D. Ghoussoub, C.F. Aissi, M. Guelton, J.P. Bonnelle, J. Chem. Soc. Faraday Trans. 86 (1990) 2775.

[15] F. Cavani, E. Etienne, R. Mezzogori, A. Pigamo, F. Trifiro, Catal. Lett. 75 (2001) 99.

[16] F. Cavani, R. Mezzogori, A. Pigamo, F. Trifiro, E. Etienne, Catalysis Today 71 (2001) 97.

[17] L. Marosi, G. Cox, A. Tenten, H. Hibst, J. Catal. 194 (2000) 140 .

[18] L. Marosi, C. Otero Arean, J. Catal. 213 (2003) 235.
[19] R. Bayer, C. Marchal-Roch, F.X. Liu, A. Teze, G. Herve, J. Mol. Catal. A: Chemical 110 (1996) 65.

[20] S. Albonetti, F. Cavani, F. Trifiro, M. Gazzano, M. Koutyrev, F.C. Aissi, A. Aboukais, M. Guelton, J. Catal. 146 (1994) 491.

[21] F.C. Jentoft, S. Klokishner, J. Kröhnert, J. Mehlsheimer, T. Ressler, O. Timpe, J. Wienold, R. Schlögl, Appl. Cat. A: General 256 (2003) 291.

[22] G. Mestl, T. Ilkenhans, D. Spielbauer, M. Dieterle, O. Timpe, J. Kröhnert, F. Jentoft, H. Knözinger, R. Schlögl, Appl. Catal. A: General $210(2001) 13$.

[23] T. Ressler, R. E. Jentoft, J. Wienold, M.M. Günter, O. Timpe, J. Phys. Chem. B 104 (2000) 6360.

[24] Designed by M. Hagelstein, T. Neisius, et al., ESRF, France, in a collaborative effort with the Fritz-Haber-Institut, Berlin, Germany

[25] T. Ressler, J. Synch. Rad. 5 (1998) 118.

[26] D.C. Koningsberger, R. Prins, X-ray Absorption Spectroscopy, Chemical Analysis, 92, Wiley, New York, 1988.

[27] J.J. Rehr, C.H. Booth, F. Bridges, S.I. Zabinsky, Phys. Rev. B 49 (1994) 12347.

[28] T. Ressler, S.L. Brock, J. Wong, S.L. Suib, J. Phys. Chem. B 103 (1999) 6407.

[29] T. Ressler, R.E. Jentoft, J. Wienold, T. Neisius, J. Catal. 210 (2002) 67.

[30] T. Ressler, J. Wienold, R.E. Jentoft, F. Girgsdies, Europ. J. Inorg. Chem. 2 (2003) 301

[31] J. Wong, F.W. Lytle, R.P. Messmer, D.H. Maylotte, Phys. Rev. B 30 (1984) 5596.

[32] J.K. Lee, V. Russo, J. Mehlsheimer, K. Köhler, R. Schlögl, Phys. Chem. Chem. Phys. 2 (2000) 2977.

[33] A. Pöppl, P. Manikandan, K. Köhler, P. Maas, P. Strauch, R. Böttcher, D. Goldfarb, J. Am. Chem. Soc. 123 (2001) 4577.

[34] M. Binnewies, M. Jaeckel, H. Willner, G. Rayner-Canham, Allgemeine und Anorganische Chemie, Spektrum Akademischer Verlag, Heidelberg (2004), according to ion radii assembled by Shannon and Prewitt with $\mathrm{d}\left(\mathrm{O}^{2-}\right)=126 \mathrm{pm}$.

[35] T. Ressler, O. Timpe, F. Girgsdies, Z. Kristall. (2005), in press. 